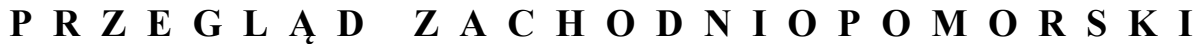 ROCZNIK XXXIII (LXII) ROK 2018 ZESZYT 3
}

\author{
TOMASZ SIKORSKI \\ Uniwersytet Szczeciński, Wydział Humanistyczny \\ e-mail: t.sikorski@poczta.fm

\section{WizJA (WYOBRAŻenIE) POWOJENNEGo PAŃSTWA W MYŚLI POLITYCZNEJ KONSPIRACYJNEJ ORGANIZACJI „UNIA”}

Słowa kluczowe: myśl polityczna, polskie państwo podziemne, organizacja konspiracyjna „Unia”, ład społeczno-ustrojowy

Keywords: political ideology, the Polish underground state, the clandestine organisation 'Union', the social and political order

Działająca w okresie II wojny światowej organizacja konspiracyjna „Unia”, mimo zainteresowania badaczy, nie doczekała się jak dotąd odrębnej monografii naukowej ${ }^{1}$. Przyczyny tego mogą być co najmniej dwie. Po pierwsze zachowało

\footnotetext{
${ }^{1}$ Wśród prac przyczynkarskich i licznych monografii dotyczących ruchu katolicko-społecznego wymienić należy: R. Łętocha, Demokracja i liberalizm w myśli polskiej chadecji lat okupacji. Na przykładzie organizacji Unia, w: Demokracja, liberalizm społeczeństwo obywatelskie. Doktryny i myśl polityczna, red. W. Kauty, Katowice 2004; tenże, Unia człowieka z człowiekiem, narodu $z$ narodem, człowieka z Bogiem. Wizja ładu międzynarodowego w publicystyce Jerzego Brauna i organizacji Unia, w: Kultura chrześcijańska w zjednoczonej Europie, red. T. Sikorski, A. Dymer, Szczecin 2007; tenże, Unionizm. Zarys koncepcji ideowych katolickiej konspiracji lat okupacji, „Almanach Historyczny” 2004, t. 4; tenże, Oportet vos nasci denuo. Myśl spoteczno-polityczna Jerzego Brauna, Kraków 2006; W. Koneczny, Unionizm jako polska doktryna katolickiej nauki społecznej, „Lithuania” 1995, nr 4; E. Ponczek, Chrześcijańska inspiracja myśli o kulturze w latach II wojny światowej, w: Religia jako źródło inspiracji w polskiej myśli politycznej XIX $i$ XX wieku, red. T. Sikorski, A. Wątor, Szczecin 2007; tenże, Kultura w poglądach społeczno-politycznych „Unii” (1940-1944), „Kultura - Oświata - Nauka” 1987, nr 1-2; C. Żerosławski, Katolicka myśl o ojczyźnie. Ideowopolityczne koncepcje klerykalnego podziemia 1939-1944, Warszawa 1987; W. Bujak, Historia Stronnictwa Pracy 1937-1946-1950, Warszawa 1950; A. Andrusiewicz, Stronnictwo Pracy 1937-1950. Zbiór studiów nad dziejami najnowszymi chadecji w Polsce,
} 
się niewiele źródeł, gdyż znaczna większość „,archiwum” Unii spłonęła w powstaniu warszawskim². Po drugie „Unia” była organizacją kadrową, elitarną, o małym zasięgu i rezonansie społecznym. Bez wątpienia to, co przykuwa uwagę badaczy, także moją, to duży, a zarazem ciekawy i oryginalny ideotwórczy i programowy dorobek unionistów.

„Unia” powstała w maju 1940 roku po połączeniu trzech elitarnych organizacji polityczno-militarnych: „Warszawianki”, „Grunwaldu” i „Nowej Polski”. Najpierw, 6 października 1939 roku, wokół urzędników warszawskiej magistrali, współpracowników prezydenta Stefana Starzyńskiego, powstała „Warszawianka”. Nazwa ruchu nawiązywała nie tylko do miejsca jego powstania, ale przede wszystkim do słynnej pieśni patriotycznej z czasów powstania listopadowego. Organizacyjny trzon „Warszawianki” tworzyli: Jan Hoppe, Cyprian Odorkiewicz, Bronisław Chajęcki, Józef Mazur, Jan Piotrowski, Tadeusz Wojciechowski, Jan Zachwatowicz, Henryk Pawłowicz i Eugeniusz Poreda. Grupa dysponowała także własnymi oddziałami bojowymi dowodzonymi przez Odorkiewicza. Większość działaczy wywodziła się z dawnych kręgów sanacyjnych, a program organizacji skupiał się głównie na sprawach ekonomicznych, w dużym stopniu dublując przedwojenne dezyderaty tzw. Pierwszej Brygady Gospodarczej³ Zasięg wpływów „Warszawianki” był znikomy - obejmował jedynie zachodnie i północne dzielnice stolicy ${ }^{4}$. Organizacja przypominała swoją strukturą ruch cywilno-wojskowy, choć nazewnictwo niektórych organów (np. Komenda Główna) sugerowało, że prowadzi ona wyłącznie działalność paramilitarną. Faktycznie nie skupiano się na pracy studyjno-programowej, nie wypracowano

Warszawa 1988; J. Majchrowski, Stronnictwo Pracy. Działalność polityczna i koncepcje programowe 1937-1945- Kraków 1979; tenże, Geneza politycznych ugrupowań katolickich. Stronnictwo Pracy, grupa „Dziś i Jutro”, Paryż 1984; W. Łęcki, Geneza i ewolucja myśli społecznej Stronnictwa Pracy 1937-1993, Toruń 2009; M. Hańderek, Geneza i początek działalności konspiracyjnej Unii, w: Polska pod okupacja 1939-1945, t. 1, red. M. Gałęzowski, Warszawa 2015; tenże, Unia i Stronnictwo Pracy w walce, Warszawa 2015; T. Sikorski, Polski Savonarola. Pisma polityczne Kazimierza Studentowicza z lat wojny i okupacji, Torun 2013, zwł. s. 38-61.

${ }^{2}$ Protokół przesłuchania Jerzego Brauna, AIPN BU, sygn. 01236/332, k. 211.

${ }^{3}$ Szerzej na temat I Brygady Gospodarczej pisze P. Janus, W nurcie polskiego etatyzmu. Stefan Starzyński i Pierwsza Brygada Gospodarcza 1926-1932, Kraków 2009.

${ }^{4}$ Jan Hoppe, Życiorys, AIPN BU, sygn. 01236/752, t. 6, k. 563; K. Popiel, Na mogiłach przyjaciól, Londyn 1966, s. 174-175. Również: A. Andrusiewicz, Stronnictwo Pracy..., s. 162; K. Popiel, Od Brześcia do Polonii, Londyn 1967, s. 264; J. Braun, K. Popiel, K. Sieniewicz, Człowiek ze spiżu, Londyn 1981, s. 72-74; B. Nietyksza, Nadzieje, złudzenia, rzeczywistość. Wspomnienia z lat 1912-1945, Warszawa 1985, s. 285-199; tenże, ,,Warszawianka”, „Warszawa Lat Wojny i Okupacji 1939-1945” 1971, z. 2, s. 299-317. 
też zwartego, kompleksowego programu politycznego. Większość dezyderatów o charakterze społeczno-ekonomiczno-politycznym zapożyczono z organizacji, w których działali jeszcze przed wybuchem wojny członkowie „Warszawianki”, a więc Straży Przedniej, Zakonu Dobra i Honoru Rzeczypospolitej, Zespołu Społeczno-Narodowego (środowisko „Gospodarki Narodowej”), grupy Jutra Pracy5. Można przyjąć, że organizacje te charakteryzował dość duży radykalizm społeczny, widoczny w postulatach dotyczących uspołeczniania środków produkcji czy przeprowadzenia reformy rolnej bez odszkodowania. W kwestiach polityki zagranicznej snuto śmiałe plany budowy sojuszu państw środkowoeuropejskich pod przywództwem Polski oraz rewindykacji terytorialnych na zachodzie, czyli pełnego dostępu do wybrzeża Bałtyku, Prus Wschodnich od Gdańska, przez Szczecin, aż po Rugię.

Praktycznie już od późnej jesieni 1939 roku „Warszawianka” próbowała rozbudować struktury organizacyjne. W grudniu została do niej włączona Służba Obrony Przeciwlotniczej, którą kierował wiceprezydent Warszawy Julian Kulski. W tym samym czasie „Warszawianka” podjęła też ścisłą współpracę z syndykatami: Związkiem Zawodowym, Pracowników Samorządowych oraz Związkiem Służby Domowej. Z „Warszawianką” współpracował również „Grunwald” - organizacja bojowa kierowana przez znanego lekarza chirurga Mirosława Leśkiewicza, Stefana Kisielewskiego, Stefana Wysokińskiego i adwokata Konrada Sieniewicza. Elitarnej grupie udało się nawet wydać kilka numerów efemerydalnego pisemka „Warta”. Program „Grunwaldu” nie był skomplikowany. Przeważały w nim treści patriotyczne, motywy antysanacyjne (krytyka ,winowajców września") oraz hasła budowy federacji państw na obszarze trzech mórz: Bałtyckiego, Czarnego i Adriatyckiego ${ }^{6}$.

\footnotetext{
${ }^{5}$ Por. J. Hoppe, Wspomnienia, przyczynki, refleksje, Londyn 1972, s. 97-101. Na temat środowiska „Jutra Pracy” pisali obszernie: T. Sikorski, ,,Narodowi piłsudczycy”. Nacjonalizm państwowy w ujęciu grupy „Jutro Pracy” (1931-1939), w: Pitsudczycy bez Pitsudskiego. Dylematy piłsudczyków po 1935 r., red. M. Wołos, Toruń 2009, s. 163-188; J. Bardach, Grupa ,Jutro Pracy” a idea konsolidacji narodowej w latach 1935-1939, „Acta Universitatis Vratislaviensis. Historia” 1981, t. 36; J.M. Majchrowski, Grupa „Jutra Pracy” wobec Obozu Zjednoczenia Narodowego, „Studia Historyczne” 1977, z. 2, s. 265-275; J. Faryś, Pitsudski i piłsudczycy. Z dziejów koncepcji polityczno-ustrojowej (1918-1939), Szczecin 1991, s. 111-113; 180-186; A. Micewski, W cieniu marszałka Piłsudskiego. Szkice z dziejów myśli politycznej II Rzeczypospolitej, Warszawa 1969, s. 209-226; G. Zackiewicz, Syndykalizm w polskiej refleksji i rzeczywistości politycznej I połowy XX wieku, Kraków 2013, s. 433-434; Nacjonalista legionowy. Wybór publicystyki Jana Hoppego do 1939 roku, wstęp i oprac. A. Meller, P. Tomaszewski, T. Sikorski, Biała Podlaska 2014, s. 25-44.

${ }^{6}$ Jan Hoppe, Życiorys..., k. 564; zob. także: C. Żerosławski, Katolicka myśl..., s. 22; B. Nietyksza, Nadzieje, złudzenia..., s. 303; J. Hoppe, Wspomnienia..., s. 303-311.
} 
Trzecie ze środowisk współtworzących Unię - „Nowa Polska” - powstało między grudniem 1939 a styczniem 1940 roku. Inicjatorem jej powstania był Zenon Tomasz Sobota, były urzędnik gminny, który już w końcu 1939 roku przystąpił do organizowania ruchu oporu w Małopolsce i na Rzeszowszczyźnie. Dołączyli do niego Tadeusz Kudliński (Kraków), Juliusz Braun (Warszawa), Julian Babiński (Warszawa) i Stefan Fleszar (Warszawa). Komórki „Nowej Polski”, oprócz Warszawy i Krakowa, działały jeszcze w Kielcach i Radomiu. Zbrojne oddziały tej organizacji szybko straciły autonomię i zostały włączone do ZWZ7 . Najprawdopodobniej jeszcze w grudniu 1939 roku wąska grupa działaczy skupiona wokół Jerzego Brauna nawiązała kontakt z „Warszawianką", następnie, wiosną 1940 roku, także z „Grunwaldem” oraz organizacją „Pobudka”. W efekcie rozmów zjednoczeniowych, w maju 1940 roku, z połączenia „Nowej Polski”, „Warszawianki” i „Grunwaldu” powstała „Unia”. Przystąpiło do niej również środowisko „Spólnoty”, którym kierował Kazimierz Studentowicz. Była to grupa byłych pracowników Banku Gospodarstwa Krajowego, od jesieni 1939 roku zatrudnionych w Spółdzielni Pracy „Spólnota”.

Jeszcze wiosną i latem 1940 roku z „Unią” związały się inne środowiska konspiracyjne: Konfederacja Niepodległościowych Organizacji Polskich (Stanisław Bukowski), Front Odrodzenia Polski (Zofia Kossak-Szczucka, ks. Franciszek Pauliński, ks. Jan Zieja, ks. Edmund Krauze, Władysław Bartoszewski, Witold Bieńkowski) oraz część Akademickiego Stowarzyszenia „Odrodzenie” (Ludwik Górski, Jerzy Turowicz, Michał Sobański, Czesław Strzeszewski) ${ }^{10}$.

Na początku 1941 roku za pośrednictwem Sobańskiego do „Unii” przystąpiła Organizacja Wojskowa „Wilki” (działała przede wszystkim na Wileńszczyźnie i Nowogródczyźnie), kierowana przez Józefa Stanisława Brücknera ${ }^{11}$. Pomimo że

\footnotetext{
${ }^{7}$ Jan Hoppe, Życiorys..., k. 565-566; Protokół przesłuchania Jerzego Brauna..., k. 33; k. 539540; J. Braun, Moja działalność społeczno-polityczna, AIPN BU, sygn. 01236/332, k. 673.

${ }^{8}$ K. Studentowicz, Życiorys, AIPN BU, sygn. 01224/752, k. 285; Protokół przesłuchania Kazimierza Studentowicza, AIPN BU, sygn. 01224/752, k. 1055; Protokół przesłuchania Jerzego Brauna..., k. 207-208. Także: A. Andrusiewicz, Stronnictwo Pracy..., s. 163; W. Bujak, Historia..., s. 84-90; J. Braun, Zarys historii i doktryny Unii (1940-1945), „Chrześcijanin w Świecie” 1985, nr 133, s. 27-29; B. Nietyksza, Nadzieje, złudzenia..., s. 302-303.

${ }^{9}$ K. Studentowicz, Życiorys..., k. 280.

${ }^{10}$ Jan Hoppe, Życiorys..., k. 565-566; Uzupełnienie do życiorysu Jana Hoppe, AIPN BU 1224/52, k. 626; Protokół przesłuchania Jerzego Brauna..., k. 503; zob. także: A. Klimontt, Wspomnienie o Zofii Kossak i FOP-ie, „Więź” 1986, nr 4, s. 83-90.

${ }^{11}$ Z. Łukawski, Pozycje bez okopów, Warszawa 1969; A.K. Kunert, Ilustrowany przewodnik po Polsce Podziemnej 1939-1945, Warszawa 1996, s. 465; także: K. Studentowicz, Życiorys...,
} 
Unia zrzeszała ludzi z kilku środowisk, nadal miała charakter elitarny i kadrowy. Warto zaznaczyć, że w jej strukturach znalazło się niemałe grono intelektualistów, na przykład Janusz Pajewski, Kazimierz Piwarski, Wacław Felczak, Jan Dąbrowski, Henryk Batowski, Czesław Strzeszewski, Kazimierz Wyka, Stefan Jaracz, Jan Kielanowski, Stanisław Leszczyński, Kazimierz Kumaniecki, Jan Zachwatowicz, Seweryn Eustachiewicz, o. Jacek Woroniecki, Henryk Dembiński, Kazimierz Libera oraz Stefan Kieniewicz.

Najważniejszym ogniwem organizacyjnym „Unii” był Komitet Naczelny. Zasiadali w nim: Jerzy Braun (prezes) oraz Jan Hoppe (wiceprezes), płk Edward Grodzki (członek), M. Sobański (członek), C. Odorkiewicz (członek) i M. Leśkiewicz (członek). Od 1942 roku do Komitetu zostali dokooptowani: Z. Kossak-Szczucka, K. Studentowicz i S. Bukowski. Oprócz Rady Naczelnej działały jeszcze Główna Komisja Rewizyjna, Sąd Organizacyjny, Walny Zjazd Delegatów oraz Rada Programowa, której zadaniem było rozwijanie i aktualizowanie bieżącego programu ${ }^{12}$. Obradom Rady przewodniczył w okresie funkcjonowania „Unii” Jerzy Braun. Warto zaznaczyć, że Rada Programowa nie była jedynie zastygłym kolegialnym ciałem statutowym, w jej ramach działały różne komisje, które pracowały nad programem politycznym: 1) Komisja Socjalna (Zygmunt Kopankiewicz, J. Hoppe, Stefan Mateja); 2) Komisja Ekonomiczna (K. Studentowicz); 3) Komisja Prawnicza (Józef Tyszkiewicz, Stefan Bruszyński, J. Zieleński); 4) Komisja Polityki Zagranicznej (J. Pajewski, M. Sobański, S. Kieniewicz, K. Sieniewicz); 5) Komisja Kulturalna (J. Zachwatowicz, K. Ragemey, Antoni Madej, T. Kudliński, Jerzy Braun, M. Perkowski); 6) Komisja Oświaty (Bronisław Chruścicki, Albin Jakiel). Z poszczególnymi komisjami współpracowali również eksperci: L. Górski, Lech Rościszewski, Bruno Sikorski, Juliusz Braun, Zbigniew Madeyski i Tomasz Kozłowski. ${ }^{13}$ Z inicjatywy S. Bukowskiego zrealizowano również w 1943 roku projekt powołania czterech Unii Sektoralnych: 1) Unia Kultury (m.in. Jerzy Braun, J. Zachwatowicz, T. Kudliński) ${ }^{14}$; 2) Unia Kobiet (m.in. Z. Kossak-Szczucka, Anna Dobrzyńska, Halina Bierówna); 3) Unia

k. 285; Protokół przesłuchania Jerzego Brauna..., k. 540-541; B. Nietyksza, Nadzieje, złudzenia..., s. 308.

12 Jan Hoppe, Życiorys..., k. 566-567; Organizacja „Unionizmu” jako ruchu ideowego [b.d.w.; b.m.w.], s. 8 i n.

${ }^{13}$ Protokół przesłuchania Jerzego Brauna..., k. 541-543.

${ }^{14}$ Z Unią Kultury współpracował afiliowany przy „Unii” Ruch Unijny Słowiańskiego Towarzystwa Kulturalnego, działający głównie w Krakowie na bazie tamtejszej komórki „Unii”. 
Pracy (m.in. Z. Madeyski, K. Studentowicz); 4) Unia Młodzieży (m.in. Jerzy Seredyński $)^{15}$. Powołanie sektorów miało z jednej strony rozładować nadmierny centralizm organizacyjny, $\mathrm{z}$ drugiej usprawnić pracę nad programem ideowym, politycznym i wychowawczym.

Wewnątrz „Unii” działały także „struktury poziome”: tzw. Kolumna, to jest ściśle zakonspirowana organizacja o technicznych zadaniach, jak choćby magazynowanie i kolportaż materiałów programowych ${ }^{16}$, oraz Instytut Europy Środkowo-Wschodniej (IEŚ-W) - komórka o eksperckim charakterze, przygotowująca raporty i programy ${ }^{17}$.

Niektórzy członkowie Komitetu po zwycięstwie ZSRR nad III Rzeszą wycofali się z czynnej działalności, uważając, że zmienia się zasadniczo koniunktura polityczna i wszelkie dyskusje nad kształtem przyszłej federacji państw środkowoeuropejskich zwyczajnie straciły rację bytu, ponieważ ta część Europy znajdzie się pod wpływami ZSRR. Na przełomie 1944/1945 roku członkowie Instytutu za pośrednictwem Karola Stojanowskiego, również współpracownika IEŚ-W, podjęli rozmowy na temat współpracy z Organizacją Ziem Zachodnich „Ojczyzna”, z inicjatywy której powstały Biuro Ziem Zachodnich Delegatury Rządu RP na Kraj, a nieco później również Uniwersytet Ziem Zachodnich i Instytut Zachodni (w 1945 r.) $)^{18}$.

Zasadniczo najlepszą formą promocji idei i programu politycznego „Unii” była prasa. Unioniści dysponowali kilkoma tytułami, na ogół dobrze zredagowanymi, na przykład: „Kultura Jutra”, „Naród”, „Miesięcznik Literacki”, „Słowo”, „Ogniwo”, „Nakazy”. W skład „Unii” wchodziły również oddziały zbrojne, którymi dowodził płk Edward Grodzki (były szef sztabu Armii Modlin) ${ }^{19}$. Oddziały unionistów zostały wcielone do ZWZ AK, choć wcześniej rozmowy na temat

\footnotetext{
${ }^{15}$ Protokół przesłuchania Jerzego Brauna..., k. 542-543.

${ }^{16}$ Tamże, k. 553-555.

${ }^{17}$ Por. T. Sikorski, Między Odra, Bałtykiem a Dniestrem. Synteza „Polski Pitsudskiego” $z$ „Polska Dmowskiego” w działalności (pracach studyjnych) Instytutu Europy Środkowej i programie politycznym konspiracyjnej organizacji „Unia” (1940-1944/1945), w: Nad Odra i Bałtykiem. Polska myśl zachodnia do 1939 roku. Twórcy - koncepcje - realizacja, red. M. Semczyszyn, T. Sikorski, A. Wątor, Szczecin 2013.

${ }^{18}$ Protokół przesłuchania Alojzego Targa, AIPN BU, sygn. 01236/332, k. 100-101; k. 126-127; Protokół przesłuchania Stanisława Miklaszewskiego, AIPN BU, sygn. 01236/332, k. 104-105; Notatka informacyjna, AIPN BU, sygn. 01236/332, k. 117. Z Instytutem Zachodnim po zakończeniu wojny podjęli współpracę J. Pajewski i K. Piwarski, zob. Instytut Zachodni w dokumentach, wybór i oprac. A. Choniawko, Z. Mazur, Poznań 2006, s. 24-267.
}

${ }^{19}$ K. Popiel, Na mogitach przyjaciót..., s. 137-139. 
scalenia prowadzono z NSZ (Stanisław Kasznica, Tadeusz Todtleben, Tadeusz Gluziński, Karol Stojanowski). Zakończyły się jednak niepowodzeniem, pomimo że płk. Grodzkiemu oferowano dowództwo nad połączonymi siłami.

$\mathrm{Na}$ tle innych organizacji konspiracyjnych „Unia”, mimo potężnego potencjału intelektualnego, nie była w stanie konkurować ze stronnictwami „wielkiej czwórki”: Stronnictwem Narodowym, Stronnictwem Pracy, Stronnictwem Ludowym i Polską Partią Socjalistyczną „Wolność Równość Niepodległość”. Stąd praktycznie już od lata 1940 roku toczono rozmowy na temat zjednoczenia z różnymi podmiotami: SN, Obozem Narodowo-Radykalnym „Szaniec”, odłamami ludowców, Ruchem „Miecz i Pług”, środowiskiem „Orki”, Chłopską Organizacją Wolności „Racławice”, Polską Organizacją Zbrojną oraz Ruchem Zjednoczenia Słowian, którym kierował Jerzy Mostowicz (ps. Jerzy Słowiański), agent gestapo $^{20}$.

Od początku 1942 roku toczyły się również rozmowy w sprawie zjednoczenia z $\mathrm{SP}^{21}$. Niemal w tym samym czasie zaproponowano liderom „Unii” rozmowy o połączeniu z rozłamowcami z SP, którzy utworzyli Stronnictwo Zrywu Narodowego (Zygmunt Felczak, Feliks Widy-Wirski). „Unii” nie odpowiadały jednak wyraźnie antyklerykalne (ateistyczne) i neopogańskie zapożyczenia ideowe reprezentowane przez działaczy przedwojennej Zadrugi, którzy również przyłączyli się do $\mathrm{SZN}^{22}$. Tak więc, po oczywistym fiasku rozmów ze SZN, w styczniu 1943 roku parafowano wstępną umowę z SP, na podstawie której „Unia” miała wejść w skład formacji chadeckiej na zasadzie autonomii, zachowując własny Komitet Wykonawczy, Radę Naczelną i Radę Programową oraz własne członkostwo. Unioniści mieli w SP bardzo silną pozycję, bowiem zasiadali w najważniejszych organach statutowych SP, zaś Jerzy Braun i Studentowicz mieli duży wpływ na wypracowane przez chadeków dokumenty programowe ${ }^{23}$. Deklarację o połączeniu „Unii” z SP parafowano ostatecznie 13 lutego 1943 roku $^{24}$. Do Zarządu Głównego SP z ramienia „Unii”

\footnotetext{
${ }^{20}$ Jerzy Braun, Życiorys, AIPN BU, sygn. 01224/752, k. 574-575; Protokół przesłuchania Jerzego Brauna..., k. 506-508; k. 543-549; Akt oskarżenia przeciwko Jerzemu Braunowi, AIPN BU, sygn. 01236/332, k. 655-666.

${ }^{21}$ Por. M. Hańderek (rec.), Tomasz Sikorski, Polski Savonarola. Pisma polityczne Kazimierza Studentowicza z lat wojny i okupacji, Toruń 2013, „Pamięć i Sprawiedliwość” 2015, nr 26, s. 252.

${ }^{22}$ Uzupełnienie do życiorysu Jana Hoppe..., k. 653-656; J. Braun, „Unia”, „Więź” 1985, nr 7-9, s. 171-205.

${ }^{23}$ Jan Hoppe, Życiorys..., k. 569 i n; J. Braun, Moja działalność..., k. 679.

${ }^{24}$ „Reforma”, 10.04.1943, nr 6; „Naród”, marzec 1943, nr 3; W. Bujak, Historia ..., s. 127-128; J. Majchrowski, Geneza politycznych ugrupowań..., s. 62.
} 
weszli: Jerzy Braun, K. Studentowicz i S. Bukowski, natomiast do władz „Unii” dokooptowano chadeków: Józefa Kwasieborskiego i Stefana B. Kaczorowskiego. Radę Programową unistów zasilił natomiast Józef Chaciński ${ }^{25}$.

Liderzy „Unii” starali się (także po zjednoczeniu z SP) uczestniczyć w różnych inicjatywach ogólnokonspiracyjnych. Świadczyło to o dużej otwartości kierownictwa na współpracę oraz dobrych kontaktach, na ogół jeszcze z okresu przedwojennego, z ludźmi wywodzącymi się z różnych przedwojennych środowisk i grup. Na przykład w 1943 roku „Unia” przystąpiła do Społecznej Organizacji Samoobrony (S.O.S), do której należały także inne ugrupowania, na przykład Stronnictwo Demokratyczne, Polski Związek Wolności, Chłopska Organizacja Wolności „Racławice”, Obóz Polski Walczącej, Front Odrodzenia Narodowego (podbudowa polityczna Tajnej Armii Polskiej), Ruch Zjednoczenia Słowian, Organizacja „Pobudka”, Korpus Bezpieczeństwa Warszawy ${ }^{26}$. Po zastrzeleniu przez żołnierzy państwa podziemnego „Jerzego Słowiańskiego” z RZS działalność S.O.S zamarła, ponieważ na jej trop wpadli Niemcy ${ }^{27}$.

Odrębną strukturą było Biuro Pracy Społecznej, powołane tuż przed wojną przez SN na potrzeby sporządzania ekspertyz w sprawach polityki społecznej i gospodarczej. Z ramienia „Unii” w pracach BPS uczestniczyli: Konrad Sieniewicz, Kazimierz Studentowicz i Tomasz Kozłowski ${ }^{28}$. Poza tym działacze Unii utrzymywali kontakty z SN, ONR, Konfederacją Narodu, Klubem Patriotów (Towarzystwo Patriotyczne: Roman Knoll, Józef Rettinger), organizacjami syndykalistycznymi, piłsudczykowskimi (np. Myślą Państwową) i ludowymi (np. Chłopska Organizacja Wolności „Racławice”). Franciszek Urbański z „Unii” był także członkiem z ramienia SP w tzw. Komitecie Antykomunistycznym, grupującym głównie polityków „czwórki” oraz SD i S.O.S. ${ }^{29}$

${ }^{25}$ Jan Hoppe, Życiorys..., k. 570-571; także: J. Majchrowski, Geneza politycznych ugrupowań..., s. 62-63.

${ }^{26}$ W S.O.S działała spora grupa unionistów, m.in. Jerzy Braun, W. Siła-Nowicki, B. Nietyksza i Z. Kossak-Szczucka, zob. B. Nietyksza, Nadzieje, złudzenia..., s. 319-320.

${ }^{27}$ Protokół przesłuchania Jana Hoppe, AIPN BU, sygn. 01224/752, k. 521-527; Protokół przesłuchania Jerzego Brauna..., k. 550-552; J. Braun, Moja działalność..., k. 680. Również: S. Fertacz, Polska myśl stowiańska w okresie drugiej wojny światowej, Katowice 2000, s.74-75; C. Żerosławski, Katolicka myśl..., s. 23.

${ }^{28}$ Jan Hoppe, Życiorys..., k. 575; Protokół przesłuchania Jerzego Brauna..., k. 511-513; ppor. B. Lisowski, Ogólna charakterystyka organizacji ,Unia”, AIPN BU, sygn. 01236/332, k. 703.

${ }^{29}$ Protokół przesłuchania Jana Hoppe..., k. 518-519; Uzupełnienie do życiorysu Jana Hoppe..., k. 629-630. 
Liderzy „Unii” uczestniczyli również czynnie w pracach Delegatury Rządu RP na Kraj. Jerzy Braun był zastępcą szefa Kierownictwa Walki Cywilnej, przewodniczącym Rady Jedności Narodowej, delegatem Rządu RP na Kraj, autorem słynnego „Testamentu Polski Walczącej” i współautorem „Manifestu do Narodu Polskiego i Narodów Zjednoczonych"30.

Jak wspomniano, baza społeczna „Unii” miała głównie charakter mieszczański i inteligencki. W skład kadry kierowniczej organizacji w okresie jej samodzielnego działania wchodzili głównie przedstawiciele profesury, akademicy, drobni urzędnicy, prawnicy (sędziowie i adwokaci), dziennikarze, zawodowi żołnierze. Mieli oni bardzo różny bagaż doświadczeń i poglądów. Znajdowali się tam piłsudczycy, narodowi katolicy, personaliści, społeczni radykałowie (np. działacze Związku Nauczycielstwa Polskiego), działacze chrześcijańsko-społeczni, a nawet socjaliści. I już choćby na podstawie tych biograficznych afiliacji „Unię” można zaklasyfikować jako organizację syntetyzującą idee chrześcijańskie ze społecznym radykalizmem, charakteryzującym ugrupowania o proweniencji postępowej.

Bez wątpienia „Unia” należała do tych środowisk konspiracyjnych, które kładły ogromny nacisk na prace studyjno-programowe. Nigdy jednak nie wypracowała w pełni kompletnego programu politycznego, będącego przede wszystkim konsekwencją dominującego w publicystyce unijnej myślenia w kategoriach ideowych, co musiało oznaczać, że kwestie pragmatyki politycznej pozostawały na marginesie zainteresowań twórców myśli politycznej. O ile unistom udało się zarysować nieco archaiczny, niedostosowany do zachodzących zmian, zapewne także mało odporny na dziejowe przeciwności koncept, była to jednak wizja tylko i wyłącznie postulatywna, trudna (czy wręcz niemożliwa) do realizacji w warunkach panujących na przełomie lat 1943/1944.

Postulatywny charakter unijnej myśli politycznej był wyrazem nieco zawężonej (czy też uproszczonej) świadomości społecznej. Jeśli bowiem przyjmiemy za Émilem Durkheimem, że świadomość społeczna to nic innego, jak tylko konglomerat wyobrażeń, symboli, wzorców, pojęć, opinii, ale także mitów i przesądów, akceptowanych przez większość społeczeństwa, to w przypadku „Unii” owa wspólnota wydaje się być właśnie mocno zawężona. Ideolodzy „Unii”, zorientowani $\mathrm{w}$ meandrach filozofii, teorii kultury, historiozofii, uprawiali refleksję,

\footnotetext{
${ }^{30}$ Najpełniejszego dotąd omówienia poglądów i działalności Jerzego Brauna dokonał R. Łętocha, ,,Oportet vos nasci denuo”. Myśl społeczno-polityczna Jerzego Brauna, Kraków 2006.
} 
która tylko w ich subiektywnym odczuciu była wspólna dla większości obywateli, choć, czemu nie można zaprzeczyć, była trwale zakorzeniona w tradycji narodowej i pamięci historycznej.

Myśliciele polityczni związani z „Unią”, zwłaszcza Jerzy Braun, wychodzili z przekonania, że największym fatalizmem polskiej polityki i myśli politycznej jest ciągłe „,dzielenie”, „podział”, słowem - nieumiejętność przełamywania tradycyjnych antynomii, szukania ideowej syntezy, skutecznego przejścia z ładu porewolucyjnego (1789 r.) do porządku łacińskiego (bożego, tradycyjnego). Owo naczelne założenie unionizmu trafnie wyrażała używana przez Brauna paremia: unia człowieka z Bogiem, unia człowieka z człowiekiem, unia narodu z narodem.

Sądzę, że nie będzie nadużyciem stwierdzenie, że na koncepcję „Nowej Polski” składały się trzy szkoły myślenia, reprezentowane przez trzech głównych myślicieli politycznych z kręgu „Unii”. Pierwszym był Jerzy Braun. W filozofii politycznej Brauna widoczne były wpływy mesjanizmu romantycznego w wydaniu Józefa Hoene-Wrońskiego, poezji Cypriana Kamila Norwida, idei Stanisława Wyspiańskiego oraz Stanisława Brzozowskiego. Od nich czerpał Braun wiarę w możliwość stworzenia podstaw pod filozofię absolutną. Ideę syntezy pozornie sprzecznych idei i pierwiastków łączył Braun z postulatem federacji państw ( $k a$ tolickie imperium apostolskie), unii Kościołów, koalicji pracy i kapitału, syntezie „kultury wysokiej” (intelektualnej) i niskiej (ludowej), syntezie „Polski Szlacheckiej” i „Polski Królewskiej”, jak również przezwyciężeniu antynomii narodu i państwa ${ }^{31}$. W zarysowanym pomyśle ustrojowym Braun starał się rozstrzygnąć „tradycyjną” antynomię „władzy od góry” (autorytet wypływający z prawa Bożego) i ,władzy od dołu” (wolność scalona w prawach człowieka). W odniesieniu do kwestii społecznej jej rozwiązanie miało polegać na tworzeniu podstaw pod ustrój pośredni między demokracją parlamentarną (realizacja ,władzy od dołu”) a dyktaturą (realizacja ,władzy od góry”) ${ }^{32}$.

${ }^{31}$ J. Bartyzel, Jerzy Braun - czlowiek i dzieło, „Tygodnik Powszechny” 1985, nr 42; tenże, Między katastrofizmem a mesjanizmem. Wstęp do historiozofii Jerzego Brauna, „Pro Fide, Rege et Lege" 1992, nr 3-4, s. 6-10; zob. także: W. Kaczocha, Historia, cele rozwoju społecznego wartości kultury i posłannictwa narodu polskiego w ujęciu Jerzego Brauna, w: tegoż, Filozofia cywilizacji i kultury: teorie filozoficzne rozwijane w Polsce w pierwszej połowie XX wieku, Poznań 1998; L. Wiśniewska-Rutkowska, Mesjanizm W. Lutosławskiego a mesjanizm wrońskistyczny J. Brauna, w: Filozofia i mistyka Wincentego Lutosławskiego, red. R. Zaborowski, Warszawa 2000; tejże, Mesjanizm Jerzego Brauna. Myślenie w perspektywie Józefa Marii Hoene-Wrońskiego, Kielce 2004; M. Szyszkowska, Jerzy Braun, „Ruch Filozoficzny” 1977, nr 1-2.

32 J. Bartyzel, Jerzy Braun... 
Nieco inną intuicję ideową można przypisać Janowi Hoppemu, przedwojennemu działaczowi i ideologowi piłsudczykowskiej (reprezentującej optykę „,nacjonalizmu państwowego”) grupy „Jutro Pracy”. Hoppe uchodził przed 1939 rokiem za jednego z rzeczników korporacjonizmu oraz idei państwa uspołecznionego. Dopiero w drugiej połowie lat trzydziestych, nie rezygnując ze syndykalistycznych poglądów, wyraźnie zbliżył się do idei nacjonalistycznych, reprezentując nurt polskiego nacjonalizmu państwowego.

Jeszcze inne były doświadczenia Kazimierza Studentowicza, ekonomisty, nieźle orientującego się również w problematyce międzynarodowej. Studentowicz, choć był uczniem prof. Adama Krzyżanowskiego, nie został nigdy klasycznym liberałem. Można nawet powiedzieć, że „zbłądził”, szukając takiego programu ekonomiki narodowej, który godziłby zasady katolickiej nauki społecznej z lewicową wrażliwością. Gdy do tego jeszcze dodamy fakt, że Studentowicz był „ekspertem” ekonomicznym środowiska neokonserwatystów z „Buntu Młodych” i „Polityki”, współautorem słynnego manifestu neoimperialnego Polska idea imperialna $^{33}$ (Warszawa 1938 r.), jawi nam się postać tyleż interesująca, co wewnętrznie skomplikowana, pod względem zaś koncepcyjnym wielonurtowa. Był więc Studentowicz człowiekiem poszukującym, politycznie jeszcze nieukształtowanym, nie w pełni dojrzałym, balansującym między marzeniami o gminnym socjalizmie, postępowym światem a chrześcijańskim ładem z czasów pierwszych chrześcijan $^{34}$.

Na kanwie tych doświadczeń, ideowych intuicji i rozpoznań wypracowano unionistyczny program „Nowej Polski”. Jego pierwsze impulsy możemy odnaleźć już w przedwojennej pracy Jerzego Brauna pt. Zagadka dziejowa Polski. Próba historiozofii (Warszawa 1938), w której wyraźnie nawiązywał do potrzeby przywrócenia ducha narodowego, polskiej misji cywilizacyjnej, a jednocześnie przełamania antynomii między narodem a państwem, autorytetem władzy a wolnością jednostki. Braun jawił się również jako rzecznik federacji narodów środkowoeuropejskich, w której Polska miałaby odgrywać mesjanistyczną rolę

\footnotetext{
${ }^{33}$ Studentowicz zredagował cały rozdział poświęcony polityce gospodarczej.

${ }^{34}$ Por. T. Przeciszewski, Radykalny chrześcijański demokrata. Kazimierz Studentowicz (19031992), „Chrześcijanin w Świecie” 1993, nr 4; tenże, Kazimierz Studentowicz - wybitny przywódca, więzień polityczny i teoretyk ruchu chrześcijańsko-społecznego w Polsce (1903-1992), „Roczniki Nauk Społecznych KUL” 1994/1995, t. 22-23, z. 1. Z najnowszych prac na szczególną uwage zasługują: T. Sikorski, Polski Savonarola ...; M. Kulesza, Myśl polityczna Kazimierza Studentowi$c z a$, Szczecin 2010 [maszynopis niepublikowanej pracy magisterskiej, napisanej pod kierunkiem prof. Adama Wątora w zbiorach prywatnych autora].
} 
„Apostoła Narodów”. Z czasów przedwojennych zachował się jeszcze jeden tekst niepublikowany, najprawdopodobniej autorstwa Brauna, w którym widać te wpływy ideowe jeszcze wyraźniej. Mowa o pochodzącym ze stycznia 1938 roku artykule Zasady, ustrój i problemy socjalno-polityczne nowego państwa polskiego. Choć tekst w wersji maszynopisu liczy niewiele ponad trzy strony, można go potraktować jako przemyślaną rekapitulację poglądów Brauna na sprawy ustrojowe. Pozwala nam również przypuszczać, dlaczego Braun już na początku okupacji nazwał organizację konspiracyjną, której przewodził, właśnie „Nowa Polska”.

Projekt „Nowej Polski” to pomysł na wspólnotę opartą na trzech klasycznych fundamentalnych cnotach: prawdzie, pięknie i dobru, połączonych z prawdami wypływającymi z Biblii i Ewangelii. W dobie kryzysu cywilizacyjnego, ale także kryzysu form ustrojowych, miała to być alternatywa między demokracją a autorytaryzmem, wolnością a zniewoleniem, kosmopolityzmem a nacjonalizmem. W Nowej Polsce - pisał Braun - „naród i państwo ustanowią jedność bezwzględną, służącą najwyższym ideałom Prawa Bożego i prawdziwego postę$\mathrm{pu}^{\prime 35}$. W materii ustrojowej proponował, aby rządy oprzeć na zasadach ideokracji, w których utrzymana zostałaby harmonia między trzema na pozór tylko sprzecznymi pierwiastkami: autorytetem, wolnością i prawem. Autorytet i autorytet państwa ogniskowały się we władzy „Piastuna” (republikańskiej Głowie Państwa) - „Zwierzchnika” odpowiedzialnego przed narodem, Bogiem i historią. Oprócz trzech tradycyjnych władz: ustawodawczej (dwuizbowy sejm, łączący przedstawicielski demos z elitarną aristoi), wykonawczej (prezydent i powoływany przez niego rząd) i sądowniczej (sądy i trybunały) miała jeszcze istnieć dodatkowa, czwarta władza: Rada Najwyższa, przypominająca swoistą „,radę mędrców” (platońskich filozofów), ludzi mądrych, cieszących się zaufaniem społecznym i autorytetem. Rada nie miała tutaj ściśle przypisanych zadań, mowa tylko o tym, że rozstrzygałaby spory siłą swojego autorytetu, zabierała głos w sprawach najważniejszych dla państwa. Poza tym państwo miało być zdecentralizowane i samorządne, z rozbudowanymi instytucjami samorządu terytorialnego, a zwłaszcza gospodarczego i kulturalnego (związki ideokratyczne) ${ }^{36}$.

Ustrój społeczno-gospodarczy „Nowej Polski” miał się opierać, według Brauna, na zasadach chrześcijańskich, dalekich zarówno od kapitalizmu, jak

${ }^{35}$ Zasady, ustrój i problemy socjalno-polityczne nowego państwa polskiego, Warszawa, 3 I 1938 rok, AIPN BU, sygn. 1564/9, k. 2.

36 Tamże, k. 2-3. 
i wszelkich form socjalistycznych. Tak zwana idea pracy twórczej, zaczerpnięta przez Brauna nie tylko od Brzozowskiego, ale i Wyspiańskiego, miała łączyć w sobie znów jedynie pozornie ze sobą sprzeczne zasady sprawiedliwości społecznej z wolnością prywatną, planowości z wolnym rynkiem. Stąd warsztat pracy właściciela nie miał być traktowany jedynie jako źródło bezpośrednich korzyści dla właściciela i źródło utrzymania dla pracownika, ale przede wszystkim jako teren pracy publicznej, wychowawczej i narodowej. Miernikiem poszczególnych jednostek, a jednocześnie prawem udziału w dochodzie społecznym miała być praca, oceniana według zasady: każdemu według jego pracy. Jednoczenie Braun kładł szczególny nacisk na pielęgnowanie etosu pracy, szczególną rolę przypisując tu inteligencji. I choć unikał klasowości, a nawet więcej - był jej zagorzałym krytykiem, to uważał, że inteligencja (zwłaszcza duchowieństwo i nauczyciele) ma ogromną, wręcz misyjną rolę do odegrania. Przyznać trzeba, że ocena kondycji polskiej inteligencji w oczach Brauna nie była najwyższa. Cechowało ją w jego przekonaniu kołtuństwo, uleganie zachodnim modom i - co najważniejsze - całkowity brak moralnego kośćca oraz umiejętności krytycznego myślenia. Inteligencja miała być przede wszystkim nośnikiem narodowych wartości i ideałów kultury, warstwą zdolną poświęcić interesy prywatne celom nadrzędnym - publicznym, ogólnonarodowym ${ }^{37}$.

W kwestiach ekonomicznych Braun opowiadał się, jak już było powiedziane, za ochroną własności prywatnej, podnosił zasadność jej upowszechnienia. Domagał się uprzemysłowienia kraju, nie tracąc z horyzontu polskiego rolnictwa. Jako pionierski można potraktować postulat, aby ludność chłopska niemogąca utrzymywać się z pracy na własnym gospodarstwie, kolonizowała tereny ziem zachodnich, które miałyby się znaleźć w przyszłych granicach terytorialnych państwa polskiego. Braun ustosunkował się także do mniejszości narodowych, które państwo powinno otoczyć opieką w duchu tradycyjnej polskiej tolerancji, pod warunkiem jednak pełnej lojalności wobec państwa. Wydaje się, że warunek ten nie dotyczył jedynie Żydów, co do roli których Braun był szczególnie krytyczny. Uważał, że po „linii etyki chrześcijańskiej” należało zapewnić narodowi polskiemu pełnię praw w dziedzinie gospodarki i kultury, a ,[n]admierna ilość Żydów winna być w Nowej Polsce ograniczona na drodze planowej emigracji,

${ }^{37}$ Tamże, k. 4-5; także: J. Braun, Polska przedmiotem dziejów, AIPN BU, sygn. 1564/4, k. $18-19$. 
kierującej Żydów do ich siedziby narodowej oraz krajów przesyconych tym elementem"38. W tej kwestii zresztą propozycje Brauna nie różniły się od propozycji obozu sanacyjnego (Obozu Zjednoczenia Narodowego) ${ }^{39}$.

Najbardziej enigmatycznie i ogólnie brzmiały te rozważania Brauna, które odnosiły się do miejsca „Nowej Polski” w systemie międzynarodowym. Wychodząc z przesłanek cywilizacyjnych (także historiozoficznych), a zarazem reasekuracji interesu narodowego, uważał, że mamy jako naród do odegrania rolę dziejową. Nie ograniczała się ona jedynie do klasycznego już ,przedmurza Europy”, ale do misji w obronie łacińskiego ładu i cywilizacji klasyczno-chrześcijańskiej, do obrony przed destrukcyjnym wpływem antywartości (ostrzegał przed masonerią) i pogaństwem (bolszewizm i narodowy socjalizm). Polska, odziana w „stare mesjanistyczne szaty”, miała być przewodnikiem innych narodów, ,apostołem cywilizacji zachodniej”, strażnikiem tradycji ${ }^{40}$.

Zarysowany niemalże w przeddzień wybuchu wojny program „Nowej Polski” zawierał zasady ogólne, które unioniści uzupełnili już w okresie II wojny światowej, dążąc do tego, aby zasady moralności chrześcijańskiej były obecne w życiu prywatnym, publicznym, w stosunkach między narodami i państwami ${ }^{41}$. Tak pisali o dyspozycjach moralnych własnego środowiska:

1) My - to jawna walka wyznawców Zasady Prawdy, Dobra, Miłości i Piękna przeciwko wyznawcom zasady kłamstwa i nienawiści; 2) My - to bezklasowa jedność narodu polskiego uznająca zupełną równość każdego Polaka i każdej Polki przed prawem Bożym i uzgodnionym z nim prawem państwowym; 3) My - to samorzutnie powstający i rozwijający się w Polsce rewolucyjny ruch moralno-polityczny i to najpierw moralny, dopiero w konsekwencji - polityczny ruch, wymierzony przeciwko wszystkim obcym i wrogim cywilizacji łacińskiej wpływom, potęgom i spiskom międzynarodowym (mamonistycznym, totalistycznym, komunistycznym, itp.), ruch podejmujący realizację zaniedbanej misji dziejowej Narodu Polskiego, 4) My - to wkraczający poza wszelkie partie front ogólnonarodowy, jednoczący wszystkich dobrych Polaków w walce o realizację w Polsce narodowego ustroju sprawiedliwości i miłości społecznej, Polaków stojących na gruncie zasad i metod cywilizacji chrześcijańskiej. 5) My - to społeczność wiadoma swych obowiązków względem Ojczyzny, Boga,

${ }^{38}$ Zasady, ustrój i problemy..., k. 4.

${ }^{39}$ Zob. J. Majchrowski, Silni-zwarci-gotowi. Myśl polityczna Obozu Zjednoczenia Narodowego, Warszawa 1985, s. 117-140.

${ }^{40}$ Zasady, ustrój i problemy..., k. 2, k. 3; Światopoglądowe podstawy unionizmu [b.m.w., b.d.w.] (maszynopis w zbiorach autora), s. 2, 3-4; J. Braun, Polska przedmiotem dziejów..., k. 17-28.

${ }^{41}$ Organizacja „Unionizmu” jako ruchu ideowego..., s. 3. 
bliźniego i siebie samego, wyznawców prawd wiary katolickiej, czyli społeczność nie bezczynnych dewotów, lecz aktywnych, konsekwentnych realizatorów ideałów Chrystusowych w życiu publicznym, społecznym i prywatnym. (...) Tworzymy się $\mathrm{z}$ nieustannie rosnących zespołów patriotów, wyłaniających się samorzutnie z całego Narodu Polskiego i ofiarnie poświęcających się wykuwaniu norm i metod realizacyjnych nowej Polski, Polski wiernej Bogu, Polski niezależnej, sprawiedliwej i wielkiej, Polski - prawdziwie Chrystusowej ${ }^{42}$.

Tworząc program „Nowej Polski”, ideolodzy „Unii” sięgali przede wszystkim do wskazań nauki chrześcijańskiej oraz tradycji i dziedzictwa polskiej myśli politycznej, starając się syntetyzować najlepsze dokonania różnych szkół politycznego myślenia. Analizując relacje między jednostką a zbiorowością, przeciwstawiono się wszelkim formom zarówno kolektywnym, jak i indywidualistycznym, wysuwając w zamian personalistyczną supozycję, w myśl której jednostka najlepiej realizuje się we wspólnocie (narodzie). Tylko żyjąc we wspólnocie, człowiek może się doskonalić i rozwijać, zachowując godność i wolność. Chcąc przełamać tradycyjną antynomię, stwierdzano, że istnieje ścisła współzależność między postępem osobowości jednostki a służbą celom społecznym. Unioniści jednocześnie podkreślali, że na relacje między człowiekiem (jednostką) a wspólnotą wpływ ma również narodowa tradycja czy szerzej - nasza psychika narodowa, będąca wyrazicielem polskiego ducha. Przekonywano, że w naszej charakterologii narodowej mieszczą się pewne cechy łacińskości, jak prymat ducha nad materią, ale również niezależność władzy religijnej od świeckiej, szacunek dla wspólnot naturalnych (rodzina, gmina, Kościół, naród), dualizm prawa państwowego i prywatnego czy ,typowo słowiańskie” umiłowanie wolności, życzliwy stosunek do obcych, bohaterstwo i męstwo, zdolność do wielkich zrywów, poświęcenie dla idei ${ }^{43}$.

Pisząc o wspólnocie, unioniści najczęściej traktowali ją tożsamo z narodem i państwem. Przez naród, za Dmowskim i Edmundem Burkem (a zarazem zgodnie z chrześcijańskim personalizmem), rozumiano ,związek przeszłych, teraźniejszych i przyszłych pokoleń, wytworzony przez wspólne dzieje, wspólną cywilizację

${ }^{42}$ Zatożenia ideowe i dyspozycja moralna ruchu unionistycznego, AIPN BU, sygn. 1607/70, k. 15; Światopoglądowe podstawy unionizmu..., s. 13-14.

${ }^{43}$ J. Braun, O chrześcijańsko-społeczny duch Nowej Polski. Jednostka a zbiorowość [b.d.w., b.m.w.], AIPN BU sygn. 1546/6, k. 2-3; Światopoglądowe podstawy unionizmu..., s. 24-30. 
i zespół właściwych danemu narodowi cech wspólnych (np. mowa, obyczaj)"4. Przynależność do narodu była wynikiem świadomego i dobrowolnego poczucia wewnętrznej łączności ze wspólnotą. Usytuowanie jednostki w ramach naturalnej wspólnoty narodowej miało również swoje bardziej pragmatyczne konsekwencje. Ideolodzy „Unii” zakładali mianowicie, że obowiązki wobec wspólnoty oraz państwa powinny być przedkładane przed jej prawami. Chodziło bowiem o ukształtowanie obywatela reprezentującego postawę etyczną w życiu publicznym. Licząc na przejęcie władzy po zakończeniu wojny, członkowie „Unii” zamierzali pracować nad wychowaniem elity narodowej, wytworzeniem środowiska „Polaków - Kierowników", twórczych moralnie, ideowo i zawodowo. Stąd w samym ruchu unionistycznym położono nacisk na postawy moralne własnych członków, „,czystość ideową", zdolność do poświęcenia się służbie publicznej.

Zgodnie ze światopoglądem prawicy chrześcijańskiej unioniści uznawali naród za organiczną całość, wewnętrznie zróżnicowaną, podlegającą naturalnej gradacji i hierarchii. W jednej z broszur programowych pisano:

Równość społeczna jest zasadą na wskroś materialistyczną, niemożliwą zresztą do osiągnięcia, albowiem przeczącą nierównościom stworzonym przez samą naturę oraz nierównościom wynikającym z konieczności hierarchii i różnicy stanów w społeczeństwie. Godząc się z nierównościami pożytecznymi i niemożliwymi do usunięcia należy jednak dążyć, ile możności, do dania wszystkim jednostkom równych szans rozwoju oraz wytępienia szkodliwych i niczym nie uzasadnionych przywilejów. Jednostki cieszące się większą siłą, zdolnościami czy też bogactwem mają specjalny obowiązek troszczenia się o dobro ogółu i przychodzenia z pomocą słabszym ${ }^{45}$.

W perspektywie unionistycznej każda wspólnota narodowa powinna być zorganizowana w państwo, naturalną strukturę niezbędną do prawidłowego rozwoju narodu. Ideolodzy „Unii” wyobrażali sobie powojenną Polskę jako państwo demokratyczne, chrześcijańskie i narodowe. Co to oznaczało? Przyjmując tzw. ideał demokratyczny, rozumiano go odmiennie od zachodnich wzorców demoliberalnych, nie literalnie, ale jako sprawną metodę rozwiązywania sporów i twórczą szkołę obywatelskiego działania. Traktowano demokrację jako formę rządzenia większości, ale woli zbiorowej nie mogły podlegać wartości naturalne

${ }^{44}$ J. Braun, O chrześcijańsko-spoteczny duch..., k. 4; Program budowy Nowej Polski, AIPN BU, sygn. 1564/4, k. 121-122.

${ }^{45}$ Założenia ideowe i dyspozycja moralna..., s. 12; zob. także: A. Skiba (K. Studentowicz), Zagadnienia społeczno-gospodarcze, Warszawa 1942, s. 31-32. 
wypływające z prawa bożego oraz zasady chrześcijańskie, które traktowano jako ponadczasowe i uniwersalne, starsze od jakichkolwiek form i reżimów rządzenia. Większość nie zawsze ma rację, można by powiedzieć, wczytując się w teksty unionistów. Spoza demokratycznych procedur wyłączano więc „zasady uniwersalne" - ponadczasowe i niezmienne, przez konserwatystów określane mianem „zakonu przyrodzonego", na nich bowiem miała się opierać demokracja określana przez unionistów jako „rząd prawdy” - „rząd idei” (ideokratyczna forma rządu) ${ }^{46}$.

Demokracja na płaszczyźnie społecznej rozwijała w człowieku pierwiastki altruistyczne, wypływające z chrześcijańskiego miłosierdzia i ewangelicznej miłości bliźniego, co w istocie zaprzeczało szowinistycznej, egoistycznej retoryce nacjonalizmu. Nawet jeśli przyjmiemy, że tezy postawione przez unionistów dalekie były od impulsów nacjonalistycznych, to poglądy na kwestie mniejszości narodowych wydawały się bardziej zbieżne, niż można byłoby sądzić z tymi, które głosił obóz narodowy. Co prawda zgodnie z tradycyjną polską tolerancją uznawano prawa mniejszości narodowych do kultywowania własnej kultury i języka, jednak uprawnienia te nie dotyczyły Żydów, Niemców, zaś Ukraińców tylko w ograniczonym stopniu. Z jednej więc strony pisano, że mniejszościom przysługują wszystkie prawa $\mathrm{w}$ takim samym stopniu, jak rdzennym mieszkańcom, pod warunkiem uznania władzy zwierzchniej, z drugiej jednak wprost zapowiadano wysiedlenie Niemców z terenów Rzeczypospolitej po zakończeniu wojny. Żydom natomiast odmawiano statusu obywatelskiego, zabraniając działalności na niwie społecznej i politycznej. W praktyce ograniczenia, jakie wymieniano, od pozbawienia czynnego i biernego prawa wyborczego, po zabronienie kierowaniem przedsiębiorstwami państwowymi, segregację w szkolnictwie (na wszystkich poziomach), czyniły z Żydów mniejszość drugiej lub trzeciej kategorii ${ }^{47}$. Za optymalne rozwiązanie uważano masową, zorganizowaną i etapową emigrację Żydów do Palestyny, współfinansowaną przez międzynarodowe organizacje żydowskie. Jeśli chodzi o Litwinów, potwierdzano, że Litwa Kowieńska jest tworem sztucznym i powinna być połączona z Polską na zasadzie Unii ${ }^{48}$. O Białorusi w zasadzie nie wspominano, co było wyraźną konsekwencją myślenia o terenach białoruskich jako historycznej części ziem polskich. Nie uważano tym samym,

\footnotetext{
${ }^{46}$ Unionizm. Podstawowe zasady doktryny [b.d.w.; b.m.w.] (na prawach maszynopisu), s. 3; Założenia ideowe i dyspozycja moralna..., k. 10.

${ }^{47}$ Zasady ustroju politycznego. Organizacja władzy zewnętrznej w państwie, AIPN BU, sygn. 1564/4, k. 46-48.

${ }^{48}$ Tamże, k. 55-58.
} 
aby Białorusini byli narodem i mieli nawet $\mathrm{w}$ minimalnym stopniu rozbudowaną świadomość narodową. Bardziej skomplikowana była tzw. kwestia ukraińska, problem zapalny polskiej polityki już przed wybuchem wojny. Unioniści, głównie ze względów geopolitycznych, ale zapewne też wychodząc z przesłanek o charakterze historycznym, nie odmawiali Ukraińcom prawa do niepodległego bytu państwowego. Uważali, że jest to jedyna realna polityka gwarantująca z jednej strony „wyzwolenie się” Ukrainy z wpływów niemieckich, z drugiej zaś umożliwiająca rozbicie Rosji, co z kolei nie naruszało jedności terytorialnej ziem między „Wisłą a Dniestrem” - „kolebki Wielkiej Polski”. Nie opowiadano się również za ograniczeniem praw mniejszości ukraińskiej w Polsce, aczkolwiek przekonywano, że Galicję Wschodnią i Wołyń należało jak najszybciej spolonizować, a mieszkającym tam Ukraińcom ograniczyć prawa obywatelskie ${ }^{49}$.

Idea państwa demokratycznego, chrześcijańskiego i narodowego nie kłóciła się z koncepcją silnego i sprawnego rządu. Warto tutaj przywołać te wyjściowe tezy ideologii „Unii”, które legły u podstaw kreacji przyszłego ustroju państwowego. „Unia” w swoim założeniu miała być ruchem przełamującym pozorne sprzeczności, antynomie: narodu i państwa, wiary i religii, jednostki i wspólnoty, Kościoła i Państwa, prawa ziemskiego i Bożego, lewicy i prawicy, etc. Opowiadała się za ustrojem antynominalnym, czyli ustrojem równoważącym i uwzględniającym antynomie (przeciwieństwa). Chcąc pogodzić intuicje prawicy i lewicy, ideolodzy unijni zamierzali odbudować, zdegradowany od czasów rewolucji francuskiej (1789 r.), autorytet władzy. Z drugiej strony mieli świadomość, że każda władza jest urządzona przez ludzi, zgodnie z aktualnymi warunkami i potrzebami narodu. Jeśli więc przyjąć, że władza pochodzi do Boga, to każda władza będzie musiała szanować chrześcijańskie zasady życia publicznego ${ }^{50}$. Jak bardzo mylili się unioniści, pokazały już pierwsze lata powojenne.

Wśród trzech pierwiastków dobrego ustroju wymieniano autorytet, wolność i prawo. Władza powinna mieć autorytet, jednostka wolność, a prawo powinno określać granice wolności jednostki. Zakładano, że na gruncie prawa musi być utrzymana harmonia i równowaga: wolności i autorytetu. Utrzymanie autorytetu wymagało trwałości i ciągłości władzy. Stąd zwierzchnikowi (monarsze, naczelnikowi bądź prezydentowi) należało przywrócić nadprzyrodzony autorytet.

${ }^{49}$ B. Korzon (K. Studentowicz), Polityka zagraniczna Polski, AIPN BU, sygn. 1564/5, k. 5366; Program budowy Nowej Polski..., k. 129-130.

${ }^{50}$ Światopoglądowe podstawy unionizmu..., s. 11-13. 
Władza bowiem pochodzi od Boga, ale udziela jej naród. Dlatego też władza jest ustanowiona zgodnie z ładem moralnym, to „rządzący” (władza) musi przestrzegać i gwarantować wolności jednostek, ponieważ prawo, którym się posługuje, jest sprawiedliwe dzięki zakorzenieniu w boskim źródle ${ }^{51}$.

Z dokumentów i tekstów publicystycznych „Unii” wyłania się ustrój przypominający klasyczną arystotelesowską politeję (rząd mieszany - regiment commixtum - ordo duplex), syntetyzującą pierwiastki: monarchiczny, arystokratyczny i demokratyczny. W ogólnym zarysie na czele państwa miał stać Suweren - Zwierzchnik (Głowa Państwa), uosabiający jednolitość i ciągłość władzy. Do kompetencji Głowy Państwa należało kierowanie polityką zagraniczną oraz kompetencje kreacyjne, związane z powoływaniem rządu, oraz tradycyjne uprawnienia w sprawach polityki obronnej i wymiaru sprawiedliwości (np. prawo łaski). Rząd miał być „ramieniem Zwierzchnika” i kierować państwem w imieniu Głowy Państwa. Nie wykluczano także wprowadzenia urzędu Kanclerza, choć o kompetencjach mniejszych niż w państwach niemieckojęzycznych. Władza ustawodawcza miała spoczywać w rękach dwuizbowego sejmu. Izba niższa miała pochodzić z wyborów powszechnych, przy czym ordynacja wyborcza przewidywała oddanie dodatkowego głosu ojcom rodzin, po jednym za każde niepełnoletnie dziecko. Zakładając, że wielodzietne rodziny w przeważającej mierze występują w środowiskach wiejskich i robotniczych, można było mówić o uprzywilejowaniu tych warstw. Izba wyższa - senat - składać się miał w części z wirylistów, nominatów (Głowy Państwa) oraz delegatów samorządów: terytorialnego, gospodarczo-zawodowego i kulturalnego. Główne zadania sejmu ograniczano do uchwalania budżetu, stanowienia praw i kontroli (choć ograniczonej) rządu.

Przewidywano również powołanie Rady Stanu, w innym miejscu pisano o Radzie Najwyższej bądź Straży Praw. Tak czy inaczej chodziło o organ opiniotwórczy (poniekąd również doradczy), nieuczestniczący bezpośrednio w procesie decyzyjnym. Pisano:

Rada Stanu nie może mieć żadnej egzekutywy, aby nie mieszała się do rządzenia. Ma ona wyrażać swobodne opinie o sprawach publicznych, biorąc za podstawę obowiązujący światopogląd i prawo moralne. W razie zamachu na ustawę ideową

${ }^{51}$ J. Braun, Polska przedmiotem dziejów..., k. 20-21; Zasady ustroju politycznego państwa polskiego po wojnie, opracowane przez Unię (marzec $1943 \mathrm{r}$.), w: Wizje Polski. Programy polityczne lat wojny i okupacji 1939-1944, wstęp, wybór i oprac. K. Przybysz, Warszawa 1992, s. 191-194; zob. także: M. Giedrojć, Wizja Polski w myśli politycznej PPS-WRN, SL, SN i SP w latach 19391945, Szczecin 2003, s. 99-114. 
państwa ze strony rządu czy innych czynników, użyje ona zastrzeżonych konstytucyjnie środków obronnych, aż do zwolnienia narodu z przysięgi na rzecz głowy państwa. (...) tak zabezpieczony rząd idei może stać się naprawdę rządem postępu. (...) Nowa Polska ma być państwem prawdziwego postępu ${ }^{52}$.

Przyszłe państwo miało być również oparte na zasadzie pełnej i wielopłaszczyznowej samorządności, dającej obywatelom możliwość uczestnictwa i partycypacji w życiu wspólnot - od rodziny, gminy, stanu zawodowego, po kulturę.

Generalny zarys ustroju „Nowej Polski” nie był ani nowatorski, ani też oryginalny. Trzon tej koncepcji był opracowany przez Jerzego Brauna jeszcze przed wybuchem wojny. Ponadto wiele proponowanych rozwiązań było bliźniaczo podobnych do tych, które zgłaszali konserwatyści (zwłaszcza projekt konstytucji autorstwa Władysława Leopolda Jaworskiego) podczas debaty nad zamianą konstytucji po przewrocie majowym ${ }^{53}$.

Ogólne zasady ustroju politycznego rozwinął, a zarazem doprecyzował, K. Studentowicz, poświęcając temu zagadnieniu obszerną broszurę pt. Zasady ustroju politycznego. Organizacja władzy wewnętrznej w państwie. W projektowanym ustroju - suweren - zwierzchnik - jest uosobieniem ciągłości i jednolitości władzy państwowej. Studentowicz deklarował się jako zwolennik ustroju monarchicznego lub quasi-monarchicznego. Na czele państwa miał stać monarcha, ewentualnie wybierany na długą kadencję prezydent (co najmniej 10-letnią). Zakres władzy króla, w zakresie relacji z parlamentem, obejmował: zwoływanie i rozwiązywanie izb, sankcję ustaw, prawo veta; w zakresie sądownictwa: prawo łaski, ale również uprawnienia, na przykład prawo wydawania rozporządzeń z mocą ustawy, prawo inicjatywy ustawodawczej oraz nominowanie niektórych ważnych urzędników państwowych (np. prezesa Najwyższej Izby Kontroli, sędziów). Monarcha lub prezydent w czasie pokoju miał pełnić funkcję Naczelnego Wodza ${ }^{54}$.

Interesująco przedstawiały się rozwiązania dotyczące elekcji zwierzchnika. Zakładano bowiem dwa warianty. Jeśli „Nowa Polska” przyjęłaby formę monarchii, następca króla zostałby wyznaczony w obrębie dynastii za zgodą Rady

\footnotetext{
${ }^{52}$ Program budowy Nowej Polski..., k. 101; zob. także: Zasady ustroju politycznego Polski, „Naród” 1943, nr 3, s. 9-11.

${ }^{53}$ Por. W.L. Jaworski, Projekt konstytucji, Kraków 1928; tenże, Myśli o ustroju państwowym, Kraków 1928; zob. także: B. Szlachta, Konserwatyści polscy wobec ustroju politycznego do 1939 roku, Kraków 2000; T. Sikorski, $W$ kręgu państwa i władzy. Koncepcje ustroju politycznego polskich konserwatystów (1926-1939), Torun 2007.

${ }^{54}$ Zasady ustroju politycznego. Organizacja władzy..., k. 29-32.
} 
Stanu. Natomiast tzw. Rada Regencyjna, kolegialne ciało przejmujące uprawnienia zwierzchnika w okresie bezkrólewia lub ciało przejściowe w okresie transformacji systemowej „,z monarchii na republikę”, miała składać się z prezesa Rady Regencyjnej, członka dynastii wyznaczonego uprzednio przez monarchę lub wybranego przez pełnoletnich członków dynastii oraz jednego przedstawiciela wybranego przez Zgromadzenie Narodowe.

Jeśli natomiast utrzymałaby ustrój republiki, proponowano zastosować rozwiązania pośrednie między amerykańskim prezydencjalizmem a kontynentalnymi (europejskimi) monarchiami konstytucyjnymi. Elekcja prezydenta, po zgłoszeniu kandydatów przez Radę Stanu i członków Zgromadzenia Narodowego, przebiegała w dwóch etapach: 1) wybór trzech kandydatów przez Zgromadzenie Narodowe spośród wszystkich zgłoszonych; 2) wybór prezydenta w referendum ludowym z trzech zgłoszonych kandydatów. Zastępcą prezydenta zostawał pierwszy prezes Rady $\mathrm{Stanu}^{55}$.

Rada Stanu miałaby być organem kolegialnym. Jej członkowie pochodziliby z wyboru: $2 / 3$ wybierałoby Zgromadzenie Narodowe, 1/3 zwierzchnik, na łączną kadencję co najmniej pięciu lat. Kompetencje tego organu byłyby rozległe, obejmowałyby między innymi zgody na przyjęcie konstytucji i najważniejszych aktów prawnych, delegowanie kandydatów na wysokie urzędy kontroli państwowej. Rada przejmowałaby również zadania Trybunału Stanu, Trybunału Konstytucyjnego, Sądu Najwyższego i Państwowej Komisji Wyborczej ${ }^{56}$.

Jeśli chodzi o sposób powoływania, skład i kompetencje rządu, projekt Studentowicza nie zawierał rozwiązań oryginalnych. Najogólniej rzecz ujmując, Rada Ministrów w jego projekcie była ciałem kolegialnym kierowanym przez premiera (prezesa Rady Ministrów). Faktycznie jednak codzienną pracą administracyjną rządu miał kierować „,minister bez teki” (współcześnie formuła ta bliższa jest zapewne wicepremierowi). Studentowicz postulował również decentralizację i kompensację uprawnień administracyjnej centralnej. Domagał się więc nie tylko likwidacji nadmiernej liczby ministerstw, ale również łączenia resortów. Niektóre kompetencje resortów miały przejąć samorządne „organy oddolne”, jak choćby rady samorządowe (syndykaty-korporacje): odrębne dla samorządu terytorialnego, zawodowego, kulturalnego, naukowego etc. ${ }^{57}$ Administracja centralna

\footnotetext{
${ }^{55}$ Tamże, k. 30.

${ }^{56}$ Tamże, k. 32-33.

${ }^{57}$ A. Skiba (K. Studentowicz), Zagadnienia spoleczno-gospodarcze..., s. 64-77.
} 
nadzorować miała również jednostki samorządu niezespolonego (np. komendy policji). Co ciekawe, nie znajdziemy w broszurze Studentowicza postulatów pełnej i całościowej decentralizacji państwa. Oczywiście ustawowo kompetencje samorządów zostałyby oddzielone od uprawnień władzy centralnej, a samorządy gminny, powiatowy i wojewódzki dysponowałyby własnymi samorządnymi organami uchwałodawczymi i wykonawczymi, niemniej sądzono, że po zakończeniu wojny trzeba będzie szczególnie dbać o zespolenie poszczególnych dzielnic, zwłaszcza że kształt terytorialny nowej Polski ulegnie zmianie, a granica zachodnia zostanie przesunięta co najmniej na linię Odry i Nysy Łużyckiej.

W przypadku urządzenia władzy ustawodawczej projekt Studentowicza próbował godzić elementy polskiej tradycji z trendami europejskimi. Autor przewidywał, że w duchu bikameralizmu parlament składać się będzie z dwóch izb: Sejmu, wybieralnego w wyborach powszechnych (pierwiastek demos) i Senatu w 1/2 pochodzącego z wyboru (ordynacja identyczna jak do Sejmu), 1/4 z wyboru dokonanego przez organy samorządowe (terytorialny i zawodowy). Kadencja obu izb wynosiłaby pięć lat, zaś ich kompetencje dotyczyłyby głównie tworzenia prawa i uchwalania budżetu ${ }^{58}$.

Sporo wątpliwości zawierały zapisy dotyczące polityki narodowościowej. W zamyśle „narodowości pokrewne” miały zapewnioną swobodę praktyk religijnych, językowych i kulturalnych. Wszystkie te tolerancyjne i demokratyczne zapisy nie dotyczyły jednak Żydów, których po pierwsze nie traktowano jako obywateli, po drugie pozbawiano praw publicznych. Żydzi nie mogli bowiem uczestniczyć w bieżącej polityce, pełnić ważnych funkcji państwowych, przynależeć do partii politycznych, wykonywać niektórych zawodów (np. lekarzy, adwokatów, inżynierów), kierować przedsiębiorstwami. A nawet więcej, „na terenie" oświaty i szkolnictwa wprost pisano o „etnicznej separacji” ${ }^{9}$.

${ }^{58}$ Zasady ustroju politycznego. Organizacja władzy..., k. 34. W części poświęconej sądownictwu projekt nie zawierał żadnych oryginalnych rozwiązań. Sądownictwo miało być niezawisłe i niezależne. Sama struktura obejmowała trzy szczeble: sądy okręgowe, apelacyjne i przysięgłe. Nie przewidywano istnienia Sądu Najwyższego. W celu większej przejrzystości i decentralizacji uprawnień rozdzielano działalność Prokuratury od sądownictwa. Nie rozbudowywano również nadmiernie organów kontroli państwowej. Oprócz NIK większość kompetencji takich organów jak Trybunał Stanu i Trybunał Konstytucyjny została scalona w Radzie Stanu.

${ }^{59}$ Tamże, k. 46-47. Także: J. Braun, Polska przedmiotem dziejów..., k. 21. Bardzo ciekawie prezentowały się także rozwiązania dotyczące działalności stronnictw politycznych. Trzeba w tym miejscu zaznaczyć, że „Unia” bardzo sceptycznie oceniała działalność nowoczesnych partii nastawionych na wyborczy sukces, grę, ścieranie się interesów, politykę gabinetową. Unioniści uważali, że w przyszłości, w sposób naturalny, „stare” partie i stronnictwa polityczne okażą 
W publicystyce i programie politycznym „Unii” dominował pogląd, że wspólnota narodowa najlepiej rozwija się poprzez działalność oddolną, „od dołu ku górze". Proponowano, aby społeczeństwo zorganizowano w samorząd narodowy: 1) samorząd rodzinny; 2) samorząd wychowawczy; 3) samorząd gospodarczy; 4) samorząd kulturalny; 5) samorząd administracyjny. W ramach działających wspólnot samorządowych przygotowano precyzyjne projekty dotyczące funkcjonowania: Naczelnej Izby Gospodarczej Izby Pracy, Rady Zakładowej, izb samorządu oświatowego i samorządu kulturalnego (Izbę Kultury Narodowej tworzyły: Izba Sztuki Narodowej, Narodowa Izba Nauki i Filozofii oraz Narodowa Izba Oświecenia i Wychowania ${ }^{60}$. Korporacyjny model organizacji życia społecznego (idea państwa stanowego), oparty na katolickich zasadach społecznych, miał w zamyśle nie tylko organizować grupy społeczne w korporacje dbające o ich interesy, ale również uwolnić inicjatywę obywatelską, a tym samym uczynić demokrację ustrojem ,prawdziwie postępowym”.

Wydaje się, że najważniejszym postulatem programowym „Unii” było podniesienie poziomu gospodarczego państwa. Sądzono, że jest to możliwe przede wszystkim poprzez uprzemysłowienie kraju, wzmocnienie drobnych i średnich przedsiębiorstw oraz modernizację rolnictwa (drobne farmerskie gospodarstwa rolne). W warstwie ideowej ustrój społeczno-gospodarczy miał się oprzeć na kilku zasadach: 1) solidaryzmu społecznego rozumianego jako przeciwieństwo podziałów klasowych; 2) poszanowania własności indywidualnej i jednoczesne jej upowszechnienie; 3) unarodowienia gospodarki (walka z obcym kapitałem, tworzenie polskich przedsiębiorstw, spółdzielni, drobnych firm usługowych etc.); 4) sprawiedliwego podziału dochodu społecznego; 5) szacunku dla pracy ${ }^{61}$.

się anachroniczne i ich rolę przejmą ruchy moralno-wychowawczo-ideowo-polityczne, zdolne do ukształtowania ,prawdziwych”, „czystych etycznie” elit. Prawo do działalności partii stronnictw podejmowała Rada Stanu na podstawie dokumentacji rejestracyjnej. Składały się na nią podpisy co najmniej 100 osób (członków założycieli), statut, wpłaty oraz życiorysy członków. Członkami partii nie mogli być Żydzi, wojskowi w służbie czynnej, urzędnicy administracji centralnej, wykluczano również duchownych.

${ }^{60}$ Zob. Zadania sztuki spoleczno-narodowe, [b.d.w.; b.m.w.] (maszynopis w zbiorach autora), k. 1-10; Światopoglądowe podstawy unionizmu..., s. 15-18; A. Skiba (K. Studentowicz), Zagadnienia społeczno-gospodarcze..., s. 67-77; Zakres działania Rady Zakładowej, AIPN BU, sygn. 1564/4, k. 29-35; Program budowy Nowej Polski..., k. 125-130; Ustrój korporacyjny, „Reforma” 1943, nr 7, s. 3-5; Samorząd społeczno-gospodarczy. Tezy dyskusyjne, „Naród” 1943, nr 4; K. Studentowicz, Dwuizbowość a samorząd, „Odnowa” 1946, nr 10, s. 4.

${ }^{61}$ Por. Założenia ideowe $i$ dyspozycja moralna ruchu unionistycznego, Warszawa, [b.d.w.] (maszynopis w zbiorach autora), s. 1-2; K. Studentowicz, Podstawowe założenia gospodarcze wg. św. Tomasz z Akwinu, AIPN BU 1607/80, k. 3-7; A. Skiba (K. Studentowicz), Zagadnienia 
Tej ostatniej zasadzie warto poświęcić nieco więcej uwagi. Przede wszystkim pracę traktowano szerzej aniżeli tylko jako wykonywane zajęcie (czynność), za które jednostka jest opłacana. W jednym z najważniejszych tekstów programowych „Unii” pisano tak:

Naczelne hasła ekonomii dynamicznej to 1) wyzwolenie społeczne pracy; 2) upowszechnienie własności; 3) piękno pracy. Praca w społeczeństwie unionistycznym nie będzie tworem ani najemnikiem kapitału, lecz obowiązkiem społecznym, aktem moralnym i posłannictwem. Oto sens wyzwolenia pracy, które znajdzie swój wyraz w całej organizacji ustroju i ustawodawstwie społecznym. Upowszechnienie własności to stan społeczny, w którym znikną rażące skrajności podziału społeczeństwa na dwie klasy: posiadaczy i najemników, a każdy będzie posiadał ten czy inny rodzaj własności i będzie zarazem człowiekiem pracy. Piękno pracy to jej charakter twórczy oraz świadomość wyższego celu, jakiemu ona ma służyć6².

W poglądach na pracę i własność prywatną pojawiały się u unionistów elementy myślenia socjalistycznego. Przede wszystkim zdawano sobie sprawę, że w powojennej Polsce trzeba będzie przyspieszyć awans społeczny chłopów i robotników (uobywatelnienie) ${ }^{63}$. Jeżeli zaś chodzi o własność prywatną, bardzo często, zwłaszcza w publicystyce Studentowicza, pojawiały się refleksy lewicowe. Wielokrotnie pisał, że między chrześcijańskimi społecznikami a socjalistami w sprawach własności i gospodarowania nie ma zasadniczych różnic. Socjaliści nie wykluczali bowiem różnych form własnościowych - od prywatnej, poprzez spółdzielczą, na państwowej (społecznej) skończywszy. Podobnie unioniści. Uważali, że naturalne prawo posiadania własności indywidualnej nie może oznaczać własności niczym nieograniczonej. Słowem - państwo ma prawo, a nawet obowiązek kontroli społecznej własności, do ograniczania jej rozporządzaniem dla dobra publicznego. ${ }^{64} \mathrm{Z}$ tych samych względów państwo mogło ingerować we

społeczno-gospodarcze..., s. 1-80; Zasady ustroju politycznego. Organizacja władzy..., k. 62-63; O chrześcijańsko-społeczny duch Nowej Polski..., s. 113-18; zob. także: W. Łęcki, Geneza i ewolucja..., s. 62-66.

${ }^{62}$ Unionizm. Podstawowe elementy doktryny..., s. 18. Także: Założenia ideowe i dyspozycja..., s. 6-7; Światopoglądowe podstawy unionizmu..., s. 18-22; Zasady ustroju politycznego. Organizacja władzy..., k. 64-66; O chrzéścijańsko-społeczny duch Nowej Polski..., s. 15-16.

63 J. Braun, Polska przedmiotem dziejów..., k. 19; Program budowy Nowej Polski..., k. 124-125.

${ }^{64}$ Zob. Założenia ideowe i dyspozycja moralna..., s. 8; K. Studentowicz, Uspolecznienie własności prywatnej, [b.d.w.; b.m.w.], s. 1-2; tenże, Ustrój pracy $i$ wspótwłasności, Warszawa 1943, s. 1-3; Program budowy Nowej Polski..., k. 125-128; Własność społeczna i prywatna w nowym 
własność rolną, albowiem podstawą ustroju rolnego miały być średnie, opłacalne, dobrze prosperujące i wydajne gospodarstwa.

Patrząc na poglądy społeczno-gospodarcze unionistów nie sposób zauważyć, że ich twórcą i głównym analitykiem był nie tylko Jerzy Braun czy członkowie specjalistycznej Komisji Ekonomicznej „Unii”, ale przede wszystkim przywoływany już K. Studentowicz. Już przed wojną dał się poznać jako znany teoretyk ekonomii młodego pokolenia. Współpracował między innymi z pismami „Bank” i „Gospodarka Narodowa” oraz „Buntem Młodych” i „Polityką”. W 1937 roku opublikował Polityke gospodarcza państwa (Warszawa 1937), uznawaną za manifest gospodarczy młodokonserwatystów. Ekonomiczne koncepcje Studentowicza, które czekają jeszcze na pełne opracowanie, wypływały z lektur prac Johna Robinsona (Studentowicz tłumaczył jego prace), Johna Maynarda Keynesa, Michała Kaleckiego, George'a Shawa Wheelera i Ferdynanda Zweiga.

W latach 1926-1928 Studentowicz uzyskał stypendium fundacji im. Tadeusza Kościuszki, co pozwoliło mu ukończyć studia na Uniwersytecie Columbia w Nowym Yorku, gdzie otrzymał tytuł doktora praw za pracę z dziedziny ekonomii i bankowości ${ }^{65}$. Był więc specjalistą w sprawach ekonomicznych i społecznych, choć trzeba przyznać, że jego koncepcje ekonomiczne, oprócz zakorzenienia w nauce społecznej Kościoła, wyraźnie czerpały z dorobku teoretyków interwencjonizmu i planowania. Niejednokrotnie dał temu wyraz w swoich pracach studyjnych oraz publicystyce ${ }^{66}$. Szczególnie ważna była ponaddwustustronicowa książka Zagadnienia społeczno-gospodarcze, napisana pod pseudonimem

ustroju społeczno-gospodarczym, „Reforma” 1943, nr 6, s. 3-4; Deklaracja społeczno-gospodarcza, „Naród” 1943, nr 5, s. 9-10; Samorząd społeczno-gospodarczy, „Naród” 1943, nr 4.

${ }^{65}$ Zob. K. Studentowicz, Życiorys..., k. 254-256; K. Studentowicz, Informacje biograficzne, AIPN BU, sygn. 1283/1382, k. 9.

${ }^{66}$ Zob. np. prace K. Studentowicza: Zabobon woluty złotej, „Gospodarka Narodowa” 1933, nr 13; Konsekwencje równania w dót, „Gospodarka Narodowa” 1935, nr 8; Postęp gospodarczy, „Bunt Młodych” 1936, nr 19; Rola gospodarcza ekonomisty, administracji państwowej, przedsiębiorcy i inżyniera, „Drogi Polski” 1937, nr 11-12; O utrwalenie i pogłębienie ożywienia gospodarczego, „Bank” 1937, nr 11; Nieznany Doboszyński, „Polityka” 1938, nr 1; Podwójne oblicz sity, „Polityka” 1938, nr 3; Granice możliwości gospodarczych Polski, „Polityka” 1938, nr 29; Problem płac pracowniczych, „Polityka” 1939, nr 10; Replika p. K. Turowskiemu, „Polityka” 1939, nr 6; Konieczność wspólzawodnictwa, „Odnowa” 1946, nr 4; Nasza chrześcijańska rewolucja, „Odnowa” 1946, nr 1; Podstawy planowania gospodarczego, „Odnowa” 1946, nr 13; Lewica katolicka, „Odnowa” 1946, nr 17; Gospodarka planowa w koncepcji katolicko-społecznej, „Tygodnik Warszawski” 1948, nr 4; Radykalizm ruchu chrześcijańsko-społecznego, „Odnowa” 1948, nr 2; Cele gospodarki planowej, „Odnowa” 1948, nr 11; Planowanie gospodarcze a moralność, „Przegląd Powszechny” 1948, nr 1; Warunki racjonalnej kalkulacji w gospodarce planowej, „Przegląd Powszechny" 1948, nr 7-8. 
Andrzej Skiba ${ }^{67}$. Dawała ona pełny i kompletny wyraz ówczesnym poglądom ekonomiczno-społecznym autora. Próbując „ożenić św. Tomasza z Karolem Marksem", jak napisał po wojnie Jan Hoppe ${ }^{68}$, Skiba vel Studentowicz dokonał dogłębnej analizy zagadnień społeczno-gospodarczych, które po dokładnej lekturze tworzą obraz wyraźnie odbiegający od zasadniczego nurtu publicystyki „Unii”. Więcej - wydaje się, że były one bliższe lewicowym teoretykom gospodarki planowej. Oczywiście z koncepcjami Studentowicza polemizowali także działacze „Unii”, sądząc, że wyjściowy program gospodarczy winien być zgodny z zasadami społecznej nauki Kościoła i polską tradycją. Trudno było jednak zakwestionować wiedzę i profesjonalizm Studentowicza, stąd niewątpliwie znaczna większość materiałów programowych „Unii” była z nim konsultowana i omawiana, a prawie wszystkie teksty publicystyczne dotyczące spraw gospodarczych wyszły spod jego pióra.

Zajmijmy się teraz miejscem geopolityki w programie politycznym „Unii”. Kwestię organizacji ładu terytorialnego w Europie oraz kształtu granic „Nowej Polski" unioniści uzależniali od dwóch przesłanek: założeń ideowych oraz zmian zachodzących w położeniu międzynarodowym. Nie ulegało bowiem wątpliwości, że nasze miejsce w Europie nie jest jedynie hasłem postulatywnym, ale będzie uzależnione od ostatecznego wyniku II wojny światowej. K. Studentowicz (pod ps. Bolesław Korzon) stworzył najważniejszy materiał programowy „Unii”, dotyczący kwestii międzynarodowych - pracy pt. Polityka zagraniczna Polski - i zakładał w nim, że ziemie położone między Bałtykiem, Morzem Czarnym a Adriatykiem, między dorzeczem Wisły, Sanu, Niemna, aż do Szczecina, od Dniepru i Dniestru z oparciem nad całym pasem naddunajskim, aż do Morza Adriatyckiego stanowią jeden kompleks geopolityczny ${ }^{69}$. Dostrzegał na tym zwartym obszarze miejsce dla cywilizacyjnej, duchowej misji, posłannictwa narodu polskiego. Polska była nośnikiem najszlachetniejszych wartości, państwem z ducha przeznaczonym do odegrania znaczącej roli w Europie Środkowej, jedynym z narodów, który byłby zdolny „,nawrócić Rosję”, przybliżyć ją do ideałów łacińskich.

${ }^{67}$ A. Skiba (K. Studentowicz), Zagadnienia społeczno-gospodarcze...

${ }^{68}$ J. Hoppe, Wspomnienia, przyczynki, refleksje..., s. 316.

${ }^{69}$ B. Korzon (K. Studentowicz), Polityka zagraniczna Polski..., s. 31; Powstaliśmy i powrócimy nad Odrę, „Naród” 1940, nr 7, s. 10-12; Prusy Wschodnie - płuca nowej Polski, „Naród” 1942, nr 10, s. 3-4; Fundamentalne zasady polskiej polityki zagranicznej, „Naród” 1943, nr 6-7; Zachodnia granica Polski, „Reforma” 1943, nr 4; s. 1-3; Wracamy nad Odre, „Reforma” 1943, nr 10, s. 6-7. 
W publicystyce „Unii” rysowały się wyraźne podziały Europy na strefy wpływów, które pokrywały się z liniami przenikających się cywilizacji. Podziały te - jak stwierdzano - można było przekroczyć, różnice między narodami ograniczyć i stworzyć wielomilionowy naród oparty na wspólnych fundamentach. Nietrudno tutaj było nie zauważyć wpływu prac rodzimych historiozofów, historyków i myślicieli politycznych: Feliksa Konecznego, Michała Bobrzyńskiego, Adama Szelągowskiego, Adama Chołoniewskiego czy też Romana Dmowskiego i Jana Ludwika Popławskiego, których Studentowicz szczególnie cenił ze względu na zmysł polityczny i wyczucie realiów geopolitycznych. Doceniał, ale nie powielał, unikając ślepego epigoństwa ${ }^{70}$. Uważał, że nasz ideał cywilizacyjny, swoiste credo polskiej polityki zagranicznej, musi się opierać na syntezie pierwiastka wschodniego (,idea jagiellońska” - „Polska Piłsudskiego”) i pierwiastka zachodniego (,Wielka Polska” - „Polska Dmowskiego”) z pierwiastkiem europejskim (,Polska Popławskiego”), uznającym rewindykacje na północy i zachodzie jako element polskiej racji stanu ${ }^{71}$.

Studentowicz przez cały okres Polski Ludowej wierny był tym racjom geopolitycznym. Doskonale obrazuje postawioną tezę jego wypowiedź z 1977 roku dla telewizji belgijskiej. Mówił wówczas:

Po II wojnie światowej odzyskaliśmy konfigurację terytorialną z okresu piastowskiego. Obecnie w tych ramach terytorialnych jesteśmy narodem jednolitym, praktycznie biorąc nie mamy mniejszości, jesteśmy religijnie, światopoglądowo jednolici. Ale życie nie jest sielanką, tylko walką. W tej chwili życie nasze jest bardzo ciężkie i trudne. Znajdujemy się pod wielką presją na różnych odcinkach i grozi nam wiele różnych niebezpieczeństw, ale w tej sytuacji musimy zawsze pamiętać, że musimy uratować i utrwalić te korzyści, które wyciągnęliśmy z II wojny światowej. A one są większe niż wyciągnął jakikolwiek naród, państwo nie wyłączając Związku Radzieckiego. My wróciliśmy do Polski piastowskiej i nad wszystkimi innymi sprawami przechodzi się do porządku dziennego, jeżeli zaczyna istnieć konflikt między zachowaniem tych osiągnięć geopolitycznych i terytorialnych a wszystkimi innymi ${ }^{7^{2}}$.

${ }^{70}$ Zob. np. K. Studentowicz, Chrześcijańska myśl spoleczna w latach okupacji (maszynopis w zbiorach autora), s. 7; tenże, Trzy fazy ducha Dmowskiego, „Naród” 1943, nr 8-9, s. 12-17.

${ }^{71}$ B. Korzon (K. Studentowicz), Polityka zagraniczna Polski..., s. 11 i n.

${ }^{72}$ Wypowiedź dla Telewizji Belgijskiej (wywiad z 11 VIII 1977 r.), AIPN BU, sygn. 1228/1058, k. 212. 
Studentowicz, pisząc Polska politykę zagraniczna na przełomie 1940/1941 roku (maszynopis pochodzi z 1941 r.), nie mógł wiedzieć, jak zakończy się II wojna światowa, nie miał również pewności, że „sojusz” niemiecko-sowiecki niebawem się rozpadnie. Twierdził, że zmiana kształtu terytorialnego Polski, ale również Europy Środkowo-Wschodniej, a więc przełamanie fatalizmu geopolitycznego, będzie możliwe jeśli Niemcy (miały się znajdować pod kontrolą demokracji zachodnich) i Rosja zostaną rozbite na mniejsze państwa. Po drugie należało przesunąć polską granicę północno-zachodnią nad Odrę i Nysę Łużycka, uzyskać Prusy Wschodnie, wysiedlić wszystkich Niemców i skonfiskować im majątek. Na wschodzie włączyć w skład państwa polskiego Wileńszczyznę, inkorporować Litwę Kowieńską (status autonomii), tereny Białej Rusi oraz Ukrainy (dawna Galicja Wschodnia, Wołyń i Podole).

Nie wykluczał jednak unii z ZSRR, pod warunkiem przyjęcia przez Sowietów cywilizacyjnych wzorców polskich (w istocie łacińskich). Polska miała znajdować się w sojuszu z Wielką Brytanią i Anglią oraz państwami nadbałtyckimi (przede wszystkim Estonią i Łotwą), a także „koalicją” skandynawską (Finlandia, Szwecja i Norwegia). Posłannictwo dziejowe Polski miało się ziścić poprzez budowę wielonarodowej federacji państw zachodniej Słowiańszczyzny. Pierwszym etapem w tym kierunku miała być unia polsko-czeska, następnie włączenie państw zachodniosłowiańskich, w dalszej kolejności Ukrainy (Ukraina Nadniestrzańska w sojuszu z Polską) i Białorusi (ścisły sojusz z Polską), Rumunii, Bułgarii oraz niektórych narodów bałkańskich ${ }^{73}$. Studentowicz pisał:

Istnieją u nas dwie orientacje w polityce zagranicznej - zachodnia i wschodnia. Jedna dążąc do odzyskania rubieży zachodnich i szerokiego oparcia na Bałtyk, druga - do szerokiego oparcia się o Morze Czarne. Jedna i druga są niewystarczające, dopiero obie stworzą realną możliwość egzystencji i pozwolą penetrować blok polsko-czesko-ukraińsko-bałtycki, który będzie mógł dać dostateczne oparcie polityczne dla ludów naddunajskich i razem z nimi utworzyć niezwyciężony wał zdolny trwać o własnych zupełnie siłach pomiędzy Niemcami a Rosją ${ }^{74}$.

${ }^{73}$ B. Korzon (K. Studentowicz), Polityka zagraniczna Polski..., s. 7 i n.; Program budowy Nowej Polski..., k. 130-133; O chrześcijańsko-społeczny duch Nowej Polski..., s. I-VI; Fundamentalne zasady polskiej polityki zagranicznej, „Naród” 1943, nr 6-7; Unia Środkowoeuropejska, „Naród” 1943, nr 8-9; Państwo Trzech Mórz, Warszawa, grudzień 1942 (na prawach maszynopisu); zob. także: M. Giedrojć, Wizja Polski w myśli politycznej..., s. 175-181; W. Łęcki, Geneza i ewolucja..., s. 50-55; C. Żerosławski, Katolicka myśl..., s. 263; R. Łętocha, Unia człowieka..., s. $185-196$.

${ }^{74}$ Światopoglądowe podstawy unionizmu..., s. 31-33. 
W publicystyce „Unii” sprawa budowy federacji pojawiła się bardzo wcześnie. Pierwsze teksty na ten temat pochodzą jeszcze z wiosny 1940 roku. Projektowano wówczas unię polsko-czeską jako wstęp do zasadniczej przebudowy Europy Środkowo-Wschodniej i stworzenia bloku międzymorskiego ${ }^{75}$. Po wybuchu wojny radziecko-niemieckiej unioniści bardziej uszczegółowili swój program. Przede wszystkim zaczęto projektować terytorialne ramy „Nowej Polski”, mocno akcentując nasze narodowe aspiracje nad Odrą i Bałtykiem. W dalszej kolejności zwracano uwagę na potrzebę misji dziejowej i stworzenia milionowego Wielkiego Narodu (wielka federacja) rozpościerającego się od Polski po państwa słowiańskie i nadbałtyckie, po Węgry i Rumunię, ostatnie ogniwa sojuszu Międzymorza. Przewidywano nawet, jak będzie zorganizowana „Nowa Federacja” („Imperium Apostolskie”) z monarchą i organami wspólnotowymi (rząd, parlament, rada związkowa, skarb i wojsko). W konsekwencji integracji subkontynentalnej zostałyby zniesione granice, wprowadzony wolny przepływ osób, kapitału i usług. W kolejnym etapie tak pojmowanego unionizmu, zgodnie z zasadą ,wolni z wolnymi, równi z równymi”, miała się dokonać przebudowa reszty Europy, a następnie świata, oparta na misji moralnej, kulturalnej i religijnej narodów chrześcijańskich ${ }^{76}$. „Po wojnie - pisał J. Braun - powinna nastąpić epoka wielkich integracji polityczno-gospodarczych, w wyniku których struktura polityczna świata zredukuje się do kilkunastu kompleksów unijnych, jak np. Unia Brytyjska, Zjednoczone Stany A.P. [Ameryki Północnej - dop. T.S.], Unia Radziecka, Unia Europy Środkowej, Unia Południowo-Amerykańska, Unia Skandynawska, Unia Łacińska, Unia Panarabska etc.” "77. Tylko taki układ stosunków międzynarodowych, odpowiadający ,polskiemu ideałowi zewnętrznemu”, miał gwarantować bezpieczeństwo narodów mniejszych i zabezpieczać je przed ekspansją wielkich mocarstw ${ }^{78}$.

Rok 1944 i wkroczenie Armii Czerwonej na terytorium Polski uświadomiły działaczom „Unii”, że większość ich postulatów i pomysłów dotyczących organizacji powojennego świata ma charakter spekulatywny i czysto intencyjny.

${ }^{75}$ B. Korzon (K. Studentowicz), Polityka zagraniczna Polski..., s. 9-14; Unia polsko-czeska, „Naród” 16 XI 1940, s. 3-5; Polska, Słowiańszczyzna, Europa, „Naród” 5 IV 1941, nr 7, s. 1-8.

${ }^{76}$ Zarys doktryny ideowej Unii..., s. 148.

${ }^{77}$ Unionizm. Podstawowe zasady doktryny..., s. 5; Notatka ze śledztwa, w: AIPN Bu, sygn. 01236/332, k. 339-343.

${ }^{78}$ Zasady ustroju politycznego. Organizacja władzy wewnętrznej w państwie, w: AIPN Bu sygn. 1564/4, k. 23-28. 
W materiałach z tego okresu rodzi się obraz zgoła inny od postulatywnych koncepcji unionistów. Nie mają oni już złudzeń co do podziału Europy na strefy wpływów. Liczyli jednak na rychły wybuch wojny między zachodnimi aliantami a ZSRR, a także utrzymanie jedności Niemiec (okupacja mocarstw zachodnich). Historia i polityka wielkich mocarstw napisała innych scenariusz. Przed narodem polskim pojawiła się nowa perspektywa, w której okupantem na następne pokolenia miała się okazać komunistyczna Rosja ${ }^{79}$.

Refleksja ideowo-polityczna „Unii” nad kształtem i wizją „Nowej Polski”, choć oryginalna i rzeczywiście przełamująca antynomie ciążące na polskiej myśli politycznej, okazała się daleka od realiów powojennej Polski. Większość działaczy „Unii” jeszcze w pierwszych latach powojennych liczyła na możliwość budowy ugrupowania chrześcijańsko-społecznego. Pierwsze aresztowania, zamknięcie „Tygodnika Warszawskiego”, z którym współpracowali, ciągła inwigilacja liderów „Unii” przez bezpiekę, wreszcie oskarżenia o współpracę z hitlerowskimi Niemcami i procesy polityczne wykluczyły elity unijne z życia społeczno-politycznego ${ }^{80}$. Podejmowane przez niektórych działaczy po 1956 roku próby

\footnotetext{
${ }^{79}$ Por. Europa Środkowa u schyłku 1944 roku, AIPN BU, sygn. 1564/1, k. 73-82; Uwagi o sytuacji w Europie Środkowej, AIPN BU, sygn. 1564/1, k. 88-94; Koncentracja sit do walki z komunizmem, „Naród” 1943, nr 2, s. 8-9; s. 609-630; Koncentracja sit do walki z komunizmem, „Naród” 1943, nr 2, s. 8; Imperializm rosyjski przedluża wojnę, „Naród” 1943, nr 3, s. 6-8; Totalna mobilizacja przeciw komunizmowi, „Naród” 1943, nr 8-9, s. 1-3; Ogólny zarys akcji komunizmu w Polsce, „Naród” 1943, nr 12, s. 13-15; Sytuacja Europy Środkowej i jej udziat w obecnej wojnie, „Słowo” 1944, nr 2.
}

${ }^{80} \mathrm{Na}$ temat „Tygodnika Warszawskiego” pisali m.in.: T. Sikorski, M. Kulesza, Niezłomni w epoce fatszywych proroków. Środowisko „Tygodnika Warszawskiego” 1945-1948; Warszawa 2013; J. Wiszniewski, Z historii prasy katolickiej w Polsce. „,Tygodnik Warszawski” 1945-1948, Kraków 1998; tenże, Koncepcje ekonomiczno-społeczne „Tygodnika Warszawskiego” 1945-1948, „Zeszyty Naukowe Uniwersytetu Jagiellońskiego. Prace z Nauk Politycznych” 1986, z. 29, s. 8199; tenże, Problematyka społeczno-polityczna „,Tygodnika Warszawskiego” 1945-1948, „Zeszyty Naukowe Uniwersytetu Jagiellońskiego. Prace z Nauk Politycznych" 1985, z. 25, s. 113-139; G. Kucharczyk, Chrześcijańsko-narodowi. Szkice z historii idei, Dębogóra 2009, s. 12-51; W. Ciechomski, Tygodnik Warszawski 1945-1948, „Ład” 1983, nr 25; W. Chrzanowski, A. Kozanecki, W 40. rocznice likwidacji „Tygodnika Warszawskiego”, „Ład” 1988, nr 38; K. Sikorski, Tygodnik Warszawski, „Przegląd Katolicki” 1986, nr 2; E. Kristanova, „,Tygodnik Warszawski” (19451948) na tle polskiej prasy katolickiej pierwszych lat po II wojnie światowej, „Łódzkie Studia Teologiczne” 2008, t. 17; tejże, „Tygodnik Warszawski” (1945-1948) a władza komunistyczna, w: Niewygodne dla władzy. Ograniczanie wolności stowa na ziemiach polskich w XIX i XX wieku. Zbiór studiów, red. D. Degen, J. Gzella, Toruń 2010, s. 357-373; R. Stopikowski, Polemiki światopogladowe na łamach ,Tygodnika Warszawskiego”, „Dzieje Najnowsze” 1995, r. 26; tenże, Problematyka gospodarczo-społeczna na łamach „Tygodnika Warszawskiego”, „Życie i Myśl” 1998, nr 4; tenże, „Tygodnik Warszawski” wobec zachodnich granic Polski, w: Z dziejów Polski i emigracji (1939-1989), red. M. Szczerbiński, T. Wolsza, Gorzów Wlkp. 2003; J. Zabłocki, Dramat „Tygodnika Warszawskiego”, „Tygodnik Solidarność” 1999, nr 15; C. Lechicki, Polska prasa 
odbudowy środowiska na zasadach „minimalizmu” i uzyskania koncesji ze strony reżimu Władysława Gomułki nie powiodły się ${ }^{81}$. Pozostali ludzie, intelektualiści, z bogatym bagażem doświadczeń. Nieliczni jednak doczekali czasów rewolucji „Solidarności”, na palcach jednej ręki można policzyć tych, którzy byli naocznymi świadkami budowy III Rzeczypospolitej.

\section{Bibliografia}

Źródta

Archiwum Instytutu Pamięci Narodowej w Warszawie

AIPN BU, sygn. 01236/332.

AIPN BU, sygn. 01224/752.

AIPN BU, sygn. 1564/ 1-9.

AIPN BU, sygn. 1607/70.

\section{Dokumenty publikowane}

Instytut Zachodni w dokumentach, wybór i oprac. A. Choniawko, Z. Mazur, Poznań 2006. Jaworski W.L., Projekt konstytucji, Kraków 1928.

Zasady ustroju politycznego państwa polskiego po wojnie, opracowane przez Unię (marzec 1943 r.), w: Wizje Polski. Programy polityczne lat wojny i okupacji 1939-1944, wstęp, wybór i oprac. K. Przybysz, Warszawa 1992.

\section{Publicystyka}

Jaworski W.L., Myśli o ustroju państwowym, Kraków 1928.

Nacjonalista legionowy. Wybór publicystyki Jana Hoppego do 1939 roku, wstęp i oprac.

A. Meller, P. Tomaszewski, T. Sikorski, Biała Podlaska 2014.

Organizacja „Unionizmu” jako ruchu ideowego [b.m.w.; b.d.w.].

katolicka 1945-1948, „Kwartalnik Historii Prasy Polskiej” 1983, nr 22, s. 71-75; M. Biełaszko, Rola prasy w kształtowaniu się środowisk katolickich w latach 1945-1948. Casus ,,Tygodnika Powszechnego”, „Tygodnika Warszawskiego” i „Dziś i Jutro”, w: Aparat represji wobec inteligencji w latach 1945-1956, red. R. Habielski, D. Rafalska, Warszawa 2010, s. 155-181; tenże, ,,Tygodnik Warszawski” i jego środowisko, „Biuletyn IPN” 2007, nr 4, s. 77-83; tenże, Środowisko „Tygodnika Warszawskiego" w latach 1945-1948, w: Warszawa miasto w opresji, red. K. Krajewski, M. Pietrzak-Merta, Warszawa 2010, s. 261-279; R. Wawryniewicz, Przyczynki do badań nad obliczem politycznym „Tygodnika Powszechnego" $i$,,Tygodnika Warszawskiego” w latach 1945-1948, „Acta Universitatis Wratislaviensis. Historia” 1991, nr 88 s. 271-291.

${ }^{81}$ Piszę o tym obszernie w tekście: Próby konsolidacji środowiska bylych działaczy Stronnictwa Pracy przed wyborami 1957 roku, w: Wybory i referenda w PRL w latach 1946-1989, red. S. Ligarski, M. Siedziako, Szczecin 2013, s. 609-630. 
Sikorski T., Kulesza M., Niezłomni w epoce fatszywych proroków. Środowisko „Tygodnika Warszawskiego" 1945-1948, Warszawa 2013.

Skiba A. (K. Studentowicz), Zagadnienia społeczno-gospodarcze, Warszawa 1942.

Studentowicz K., Uspołecznienie własności prywatnej [b.m.w.; b.d.w.].

Studentowicz K., Ustrój pracy i współwłasności, Warszawa 1943.

Światopoglądowe podstawy unionizmu [b.m.w.; b.d.w].

Unionizm. Podstawowe zasady doktryny, [b.m.w.; b.d.w.].

Zadania sztuki spoleczno-narodowe [b.m.w.; b.d.w.].

Założenia ideowe i dyspozycja moralna ruchu unionistycznego, Warszawa [b.d.w.].

Wspomnienia, pamiętniki

Chrzanowski W., Kozanecki A., W 40. rocznicę likwidacji „Tygodnika Warszawskiego”, „Ład” 1988, nr 38.

Hoppe J., Wspomnienia, przyczynki, refleksje, Londyn 1972.

Klimont A., Wspomnienie o Zofii Kossak i FOP-ie, „Więź” 1986, nr 4.

Łukawski Z., Pozycje bez okopów, Warszawa 1969.

Nietyksza B., Nadzieje, złudzenia, rzeczywistość. Wspomnienia z lat 1912-1945, Warszawa 1985.

Popiel K., Na mogiłach przyjaciót, Londyn 1966.

Popiel K., Od Brześcia do Polonii, Londyn 1967.

\section{Opracowania}

Andrusiewicz A., Stronnictwo Pracy 1937-1950. Zbiór studiów nad dziejami najnowszymi chadecji w Polsce, Warszawa 1988.

Aparat represji wobec inteligencji w latach 1945-1956, red. R. Habielski, D. Rafalska, Warszawa 2010.

Bardach J., Grupa „Jutro Pracy” a idea konsolidacji narodowej w latach 1935-1939, „Acta Universitatis Vratislaviensis. Historia” 1981, t. 36.

Bartyzel J., Jerzy Braun - człowiek i dzieło, ,Tygodnik Powszechny” 1985, nr 42.

Bartyzel J., Między katastrofizmem a mesjanizmem. Wstep do historiozofii Jerzego Brau$n a$, ,Pro Fide, Rege et Lege” 1992, nr 3-4.

Biełaszko M., ,Tygodnik Warszawski” i jego środowisko, „Biuletyn IPN” 2007, nr 4.

Bujak W., Historia Stronnictwa Pracy 1937-1946-1950, Warszawa 1950.

Ciechomski W., Tygodnik Warszawski 1945-1948, „Ład” 1983, nr 25.

Demokracja, liberalizm społeczeństwo obywatelskie. Doktryny i myśl polityczna, red. W. Kauty, Katowice 2004.

Faryś J., Piłsudski i piłsudczycy. Z dziejów koncepcji polityczno-ustrojowej (1918-1939), Szczecin 1991. 
Wizja (wyobrażenie) powojennego państwa w myśli politycznej konspiracyjnej... 187

Giedrojć M., Wizja Polski w myśli politycznej PPS-WRN, SL, SN i SP w latach 19391945, Szczecin 2003.

Hańderek M., Unia i Stronnictwo Pracy w walce, Warszawa 2015.

Janus P., W nurcie polskiego etatyzmu. Stefan Starzyński i Pierwsza Brygada Gospodarcza 1926-1932, Kraków 2009.

Kaczocha W., Filozofia cywilizacji i kultury: teorie filozoficzne rozwijane $w$ Polsce w pierwszej połowie XX wieku, Poznań 1998.

Koneczny W., Unionizm jako polska doktryna katolickiej nauki społecznej, „Lithuania” 1995, $\mathrm{nr} 4$.

Kristanova E., „Tygodnik Warszawski” (1945-1948) na tle polskiej prasy katolickiej pierwszych lat po II wojnie światowej, „Łódzkie Studia Teologiczne” 2008, t. 17.

Kucharczyk G., Chrześcijańsko-narodowi. Szkice z historii idei, Dębogóra 2009.

Kulesza M., Myśl polityczna Kazimierza Studentowicza, Szczecin 2010 [maszynopis niepublikowanej pracy magisterskiej, napisanej pod kierunkiem prof. Adama Wątora w zbiorach prywatnych autora].

Kultura chrześcijańska w zjednoczonej Europie, red. T. Sikorski, A. Dymer, Szczecin 2007.

Kunert A.K., Ilustrowany przewodnik po Polsce Podziemnej 1939-1945, Warszawa 1996.

Lechicki C., Polska prasa katolicka 1945-1948, „Kwartalnik Historii Prasy Polskiej” 1983, nr 22.

Łęcki W., Geneza i ewolucja myśli społecznej Stronnictwa Pracy 1937-1993, Toruń 2009.

Łętocha R., Oportet vos nasci denuo. Myśl społeczno-polityczna Jerzego Brauna, Kraków 2006.

Łętocha R., Unionizm. Zarys koncepcji ideowych katolickiej konspiracji lat okupacji, „Almanach Historyczny” 2004, t. 4.

Majchrowski J., Geneza politycznych ugrupowań katolickich. Stronnictwo Pracy, grupa „Dziś i Jutro”, Paryż 1984.

Majchrowski J., Silni - zwarci - gotowi. Myśl polityczna Obozu Zjednoczenia Narodowego, Warszawa 1985.

Majchrowski J., Stronnictwo Pracy. Działalność polityczna i koncepcje programowe 1937-1945, Kraków 1979.

Majchrowski J.M., Grupa „,Jutra Pracy” wobec Obozu Zjednoczenia Narodowego, „Studia Historyczne" 1977, z. 2.

Micewski A., W cieniu marszałka Piłsudskiego. Szkice z dziejów myśli politycznej II Rzeczypospolitej, Warszawa 1969.

Niewygodne dla władzy. Ograniczanie wolności słowa na ziemiach polskich w XIX i XX wieku. Zbiór studiów, red. D. Degen, J. Gzella, Toruń 2010.

Nad Odra i Battykiem. Polska myśl zachodnia do 1939 roku. Twórcy-koncepcje - realizacja, red. M. Semczyszyn, T. Sikorski, A. Wątor, Szczecin 2013. 
Nietyksza B., ,,Warszawianka”, „Warszawa Lat Wojny i Okupacji 1939-1945” 1971, z. 2. Pitsudczycy bez Piłsudskiego. Dylematy piłsudczyków po 1935 r., red. M. Wołos, Toruń 2009.

Ponczek E., Kultura w poglądach społeczno-politycznych „Unii” (1940-1944), „Kultura - Oświata - Nauka”, 1987, nr 1-2.

Przeciszewski T., Kazimierz Studentowicz - wybitny przywódca, więzień polityczny $i$ teoretyk ruchu chrześcijańsko-społecznego w Polsce (1903-1992), „Roczniki Nauk Społecznych KUL" 1994/1995, t. 22-23, z. 1.

Przeciszewski T., Radykalny chrześcijański demokrata. Kazimierz Studentowicz (19031992), „Chrześcijanin w Świecie” 1993, nr 4.

Religia jako źródło inspiracji w polskiej myśli politycznej XIX i XX wieku, red. T. Sikorski, A. Wątor, Szczecin 2007.

Sikorski K., Tygodnik Warszawski, „Przegląd Katolicki” 1986, nr 2.

Sikorski T., W kręgu państwa i władzy. Koncepcje ustroju politycznego polskich konserwatystów (1926-1939), Toruń 2007.

Stopikowski R., Polemiki światopogladowe na łamach „Tygodnika Warszawskiego”, „Dzieje Najnowsze” 1995, r. 26.

Stopikowski R., Problematyka gospodarczo-społeczna na łamach „Tygodnika Warszawskiego”, „Życie i Myśl” 1998, nr 4.

Szlachta B., Konserwatyści polscy wobec ustroju politycznego do 1939 roku, Kraków 2000 .

Szyszkowska M., Jerzy Braun, „Ruch Filozoficzny” 1977, nr 1-2.

Warszawa miasto w opresji, red. K. Krajewski, M. Pietrzak-Merta, Warszawa 2010.

Wawryniewicz R., Przyczynki do badań nad obliczem politycznym „Tygodnika Powszechnego” $i$,Tygodnika Warszawskiego” w latach 1945-1948, „Acta Universitatis Wratislaviensis. Historia" 1991, nr 88.

Wiszniewski J., Koncepcje ekonomiczno-społeczne „Tygodnika Warszawskiego” 1945 1948, „Zeszyty Naukowe Uniwersytetu Jagiellońskiego. Prace z Nauk Politycznych" 1986, z. 29.

Wiszniewski J., Problematyka społeczno-polityczna „Tygodnika Warszawskiego” 19451948, „Zeszyty Naukowe Uniwersytetu Jagiellońskiego. Prace z Nauk Politycznych" 1985, z. 25

Wiszniewski J., Z historii prasy katolickiej w Polsce. „,Tygodnik Warszawski” 1945-1948, Kraków 1998.

Wiśniewska-Rutkowska L., Mesjanizm Jerzego Brauna. Myślenie w perspektywie Józefa Marii Hoene-Wrońskiego, Kielce 2004.

Wiśniewska-Rutkowska L., Mesjanizm W. Lutosławskiego a mesjanizm wrońskistyczny J. Brauna, w: Filozofia i mistyka Wincentego Lutostawskiego, red. R. Zaborowski, Warszawa 2000. 
Wizja (wyobrażenie) powojennego państwa w myśli politycznej konspiracyjnej... 189

Wybory i referenda w PRL w latach 1946-1989, red. S. Ligarski, M. Siedziako, Szczecin 2013.

Z dziejów Polski i emigracji (1939-1989), red. M. Szczerbiński, T. Wolsza, Gorzów Wlkp. 2003.

Zabłocki J., Dramat „Tygodnika Warszawskiego”, „Tygodnik Solidarność” 1999, nr 15.

Zackiewicz G., Syndykalizm w polskiej refleksji i rzeczywistości politycznej I połowy XX wieku, Kraków 2013.

Żerosławski C., Katolicka myśl o ojczyźnie. Ideowopolityczne koncepcje klerykalnego podziemia 1939-1944, Warszawa 1987.

\begin{abstract}
Abstrakt
W artykule przedstawiono spekulatywne poglądy, wizje i koncepcje konspiracyjnej organizacji „Unia” na powojenny ład państwowy. Analizą objęto: ustrój polityczny, społeczny, ekonomiczno-gospodarczy, geopolitykę i kształt granic oraz kulturę. Ponadto uwzględniono kwestię mniejszości narodowych i przewidywane scenariusze zmian (ewolucji) w stosunkach międzynarodowych. Wykorzystano materiały źródłowe (archiwalia, dokumenty publikowane, prasę, wspomnienia i pamiętniki i publicystykę) oraz opracowania (prace zwarte i artykuły naukowe).
\end{abstract}

\title{
A Vision (Visualisation) of the Post-War State in the Political Ideology of the Clandestine Organisation 'Union' (Polish: “Unia”)
}

\begin{abstract}
The article presents speculative views, visions and concepts of the clandestine organisation 'Union' on the post-war state order. The following things have been analysed: the political and social system, the economic system, geopolitics, the shape of borders, culture and the question of national minorities. In addition, the article includes a predicted scenario of changes (evolution) in international relations. The article is based on various sources (archival materials, published documents, press and memoirs), monographs and academic articles.
\end{abstract}

